\title{
Determining Product Development and Consumer Strategies with Food Texture-Aroma Interactions
}

\author{
Gokce Keser \\ Bursa Uludag University, Faculty of Agriculture, \\ Department of Food Engineering, Bursa-Turkey \\ E-mail: gokcekeser@uludag.edu.tr \\ Tulay Ozcan (Corresponding author) \\ Bursa Uludag University, Faculty of Agriculture, \\ Department of Food Engineering, Bursa-Turkey \\ E-mail: tulayozcan@uludag.edu.tr
}

\begin{abstract}
While the acceptance or rejection of consumers is based on a series of mental preferences, it emphasizes certain values, attitudes, expectations, and dietary preferences in the development of products. New functional components, additives that improve texture and sensory properties, and new technologies that extend shelf life also encourage new product development with impressive opportunities. However, the variety of cross-modal interactions that occur between aroma, taste, and texture depending on the food matrix during food consumption makes it very complicated to explain this perception with the individual's physiological state and habits. Individuals experience many sensations when eating or drinking, such as taste, smell, touch, warmth, vision, sound, and sometimes pain and irritation. Although this versatile sensory experience forms the basis of perceived aroma and texture, some sensations are perceived individually differently than others. Understanding the mechanisms involved in food sensory perception is the basis of consumer studies. This review explains how all these sensations interact on both perceptual and physical levels.
\end{abstract}

Keywords: Food Texture, Aroma, Product Development, Consumer Strategies

DOI: $10.7176 /$ JSTR/6-10-04

\section{Gıda Tekstürü-Aroma Etkileşimleri ile Ürün Geliştirme ve Tüketici Stratejilerini Belirleme}

\begin{abstract}
Özet
Tüketicilerin yiyecekleri kabul veya reddi bir dizi zihinsel tercihlere dayanmakla birlikte, ürünlerin geliştirilmesi sürecinde belirli değerleri, tutumları, beklentileri ve diyet tercihlerini ön plana çıkarmaktadır. Yeni fonksiyonel bileşenler, tekstür ve duyusal özellikleri geliştiren katkılar ve raf ömrünü uzatan yeni teknolojiler de etkileyici firsatlar ile yeni ürün geliştirmeyi teşvik etmektedir. Bununla birlikte, gıda tüketimi sırasında gıda matriksine bağlı olarak aroma, tat ve tekstür arasında meydana gelen çapraz-model etkileşimlerinin çeşitliliği, bireyin fizyolojik durumu ve aynı zamanda alışkanlıkları nedeniyle bu algıyı açıklamayı oldukça karmaşık bir hale dönüştürmektedir. Bireyler, yemek yerken veya içerken, tat, koku, dokunma, sıcaklık, görme, ses ve bazen ağrı ve tahriş gibi çok sayıda duyum yaşamaktadır. Bu çok yönlü duyusal deneyim, algılanan aroma ve tekstürün temelini oluştursa da bazı duyumlar bireysel olarak diğerlerinden daha farklı algılanmaktadır. Gıda duyusal algısında yer alan mekanizmaları anlamak, tüketici çalışmalarının temelini oluşturmaktadır. Bu derleme, tüm bu duyumların hem algısal hem de fiziksel düzeyde nasıl etkileşimde olduğunu açıklamaktadır.
\end{abstract}

Anahtar kelimeler: Gıda Tekstürü, Aroma, Ürün Geliştirme, Tüketici Stratejileri

29 | P a g e

www.iiste.org 


\section{Giriş}

Gıdalar; bileşimi, yapısı ve fonksiyonelliği açısından oldukça karmaşık bir matrikse sahiptirler. Özellikle çiğneme sırasında algılanan gıda tekstürü ise tükeci beğenisini etkileyen en önemli duyusal özelliktir. Gıdaların ağızda fiziksel olarak işlenmesi; 1sırma, çiğneme, tükürük ile birleştirme, bolus (çiğnenmiş durumdaki yiyecek kütlesi, lokma) oluşturma ve yutma aşamaları ile şekillenen çok aşamalı bir işlem dizisinden oluşmaktadır. Tüketici tercihlerini değerlendirmek için çok sayıda yöntem bulunmakla birlikte, pek çoğu gıdaların reolojik ve mekanik davranışlarını anlamaya odaklanmaktadır. Burada gıda reolojisi, dış kuvvetlerin etkisi altındaki bir cisimde meydana gelen her türlü deformasyon ve akış ile ilgilenirken, triboloji ya da ince film reolojisi, gıdanın ağızda çiğnenirken ortaya çıkan yapısını açıklayarak, tükürük, yüzey özellikleri, gıda, dil ve damak gibi ağızın bölümleri arasındaki sürtünme kuvvetleri tarafından kayganlaştırma etkisi ile ortaya çıkan alanları ifade etmektedir Aletsel tekstür ölçümleri ise tüketicinin çiğneme işlemini bir anlamda taklit etmektedir. Ancak, bugüne kadar, gıdaların ağızda işlenmesi sırasında tekstür algılama sürecini her yönü ile anlayabilecek ideal bir teknik açıklanmamaktadır (Sethupathy ve ark. 2020).

Gelişen dünya düzeninde tükettikleri besinler konusunda her zaman seçici olan bireyler, son yıllarda duyusal algılar dışında gıdalarda besinsel ve fonksiyonel özellikleri de bir arada görme isteğindedirler. Gıda dokusu ya da tekstürü, görsel, işitsel, dokunsal ve kinestetik duyular ile ve/veya çeşitli objektif ölçümlerden biri veya daha fazlası kullanılarak öznel olarak algılanabilen en karmaşık duyusal özellik olarak tanımlanmaktadır. Gıda tekstürünün değerlendirilmesi yeni ürünlerin geliştirilmesi için son derece önemli olan bir parametredir. Örneğin, yüksek lif ya da çeşitli ilave bileşenleri içeren bazı gıdalar yüksek besin değerine sahip olmalarının dışında üretim sürecinde ve tüketici beğenisi açısından zorluklar oluşturabilmektedirler. Belirtilen bu özellikler, yeni ürün geliştirmede beslenme, duyusal ve teknolojik özellikler arasındaki kritik dengeyi açıklamaktadır (Bourne, 2002; Chen, 2014, 2015).

Gıda matriksi, yap1 ve tekstürünü oluşturan ve farklı çözülebilir özellikteki proteinler ve karbonhidratları içeren ve bu yapısal polimerlerin ilişkisinin baskın olduğu karmaşık bir sistemdir. Proteinler ve karbonhidratlar tekstürün temel yapı bileşenleridir (Özdemir ve Özcan, 2019) (Şekil 1). Gıdaların temel tat özellikleri tatlı, ekşi, tuzlu, acı ve umami olarak ayrılmaktadır ve çoğunlukla suda çözünür küçük moleküllü bileşikler de bu özelliği yönetmektedir (Lindemann, 2001).

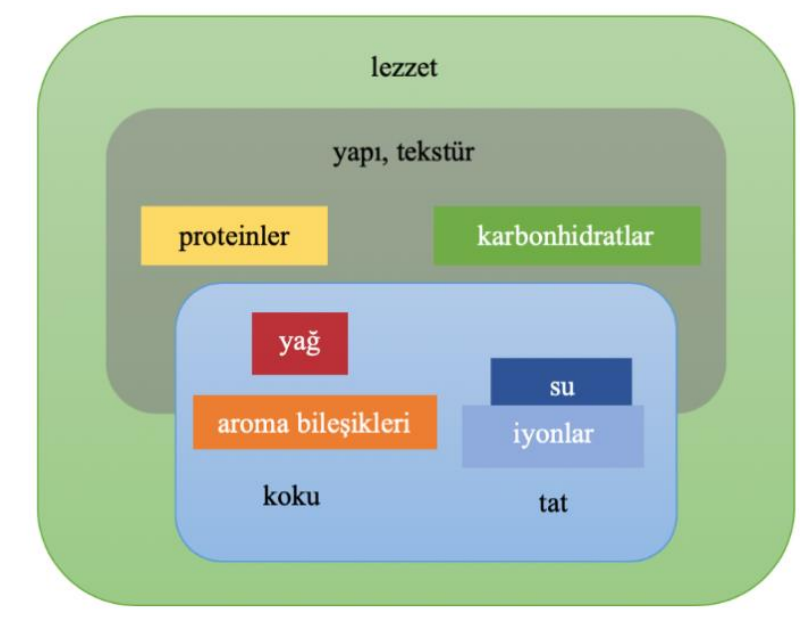

Şekil 1. Gıda bileşenlerinin sınıflandırılması (Vilgis, 2013)

\section{Gıdaların Ağızda Fiziksel Olarak İşlenmesi ve Duyusal Özellik Algısı}

Beslenmede, gıdanın makro yapısı ya da makroskopik şekli/yüzeyi, gıda parçacı̆̆ı ağız içine alındığında ilk izlenim olarak belirlenmekte, görünmeyen bir dizi süreçte gıdaların genel beğenisini, tat ve aroma algısını yönlendirmektedir. Gıdaların ağızda fiziksel olarak işlenmesi, mekanik yıkımı, kolloidal dengesizliği, biyokimyasal değişiklikleri ve yutulan gıdaların duyusal algısını eşzamanlı olarak kapsayan dinamik ve çok aşamalı bir süreçtir (Chen, 2014, 2015). Yutulan gıdadaki mekanik deformasyon ya da akış; boyut küçültme, tükürük ile kayganlaştırma/ıslatma, sıcaklık değişikliklerine bağlı faz modifikasyonu ve gıda kıvamındaki değişiklik, gıda partiküllerinin kolayca yutulabilecek bir bolus (bir gıdayı mekanik olarak küçültürken tükürük ile karıştırılması) oluşturmak için kümelenmesi

30 | P a g e

www.iiste.org 
şeklinde gerçekleşmektedir (Chen, 2008; Foster ve ark. 2011; Chen ve Stokes, 2012). Ağız sistemindeki duyusal tekstür algısı, gıdanın yapısına bağlı karmaşık bir duygudur. Tekstür ve ağız hissi tüketicinin kabul edilebilirliğini etkilemekte; bu nedenle de tekstürün değerlendirilmesi ve ölçülmesi önem taşımaktadır (Prakash ve ark. 2013). Gıdaların tekstürüne ait duyusal algı, ağız boşluğunda işlenen gıdanın çeşidi, fiziksel durumu, reolojik özellikleri, mikro yapısı ve yüzey özellikleri gibi çeşitli niteliklerine bağlı olmaktadır (Kravchukve ark. 2012). Genel olarak gidalar duyusal ve reolojik özelliklerine göre dört gruba ayrılmaktadır (vanVliet ve ark. 2009; Stieger ve van de Velde, 2013) (Çizelge 1).

Çizelge1. Duyusal ve reolojik özelliklerine göre gıdaların sınıflandırılması (Sethupathy ve ark. 2020)

\begin{tabular}{|c|c|c|c|}
\hline & $\begin{array}{l}\text { Reolojik / Duyusal } \\
\text { Özellikler }\end{array}$ & $\begin{array}{l}\text { Ağızda Fiziksel } \\
\text { İşleme }\end{array}$ & Gıda Çeşidi \\
\hline Sivi gidalar & Akışkan & Yutmadan önce çiğneme yok & $\begin{array}{l}\text { Süt, yoğurt, çeşitli } \\
\text { içecekler }\end{array}$ \\
\hline $\begin{array}{l}\text { Yarı katı } \\
\text { gıdalar }\end{array}$ & Akışkan olmayan & $\begin{array}{l}\text { Çoğunlukla dil ve damak } \\
\text { arasında sikıştırılmış, azı } \\
\text { dişleri kullanılmaz }\end{array}$ & Puding, muhallebi \\
\hline $\begin{array}{l}\text { Yumuşak } \\
\text { gidalar }\end{array}$ & Gevrek olmayan & $\begin{array}{l}\text { İlk olarak azı dişleri arasında } \\
\text { çiğneme }\end{array}$ & Peynir, işlenmiş et \\
\hline Sert gidalar & Gevrek & $\begin{array}{c}\text { Azı dişleri arasında } \\
\text { çiğneme/ezme ve karakteristik } \\
\text { sesler üretir }\end{array}$ & $\begin{array}{c}\text { Kraker, çiğ sebze, elma } \\
\text { vb. }\end{array}$ \\
\hline
\end{tabular}

Bugüne kadar, gıdaların yutulması sırasında, insanın ağız boşluğunda meydana gelen tüm dinamik değişiklikleri tespit edebilen ve ölçebilen tek bir sistem veya değerlendirme tekniği bulunmamaktadır. Son zamanlarda, gıdaların tekstür ölçümü alanında ve gıda etkileşimlerini tespit edebilmek amacıyla, tribolojinin önemi üzerine araştırmalar yapılmıştır (Sethupathy ve ark. 2020). Triboloji; makine mühendisliğinde büyük ölçüde malzemelerin sürtünmesi, aşınması ve yağlanması ile, polimer bilimi, tip, kozmetik, (Duprat-de-Paule ve ark. 2018) nanobilim, (Ermakov ve Myshkin, 2018) ve otomobil gibi birçok alanın uygulamalarında yaygın olarak kullanılmaktadır (Shafı ve ark. 2018). Gıdaların ağızda fiziksel olarak işlenmesi sırasında triboloji kavramı, tekstür algısında önemli bir rol oynamaktadır. Homojenize sütün kremsi yapıda olması ve ağızı kaplaması, çikolatanın ağızdan arındırılması gibi oral triboloji ile ilgili çalışmalarla ağız boşluğundaki tekstürel algı araştırılmıştır (Carvalho-da-Silva ve ark. 2013).

Gıdaların fiziksel olarak ağızda işlenmesi son derece dinamik bir gıda parçalanma süreci ve ağızda duyusal özelliklerin algılanması işlemidir (Fiszman ve Tarrega, 2018). Tüm bu süreç sinir sistemi ve beyin tarafindan kontrol edilmektedir (Wang ve Chen, 2017). Ağızda işlenme süreci; oral fizik, oral fizyoloji ve oral psikoloji olmak üzere üçe ayrılmaktadır (Chen, 2014). Oral fizik, uygulanan fiziksel ve mekanik kuvvetler ile gıda tekstürünün duyusal özelliklerinin algılanmasının üzerindeki etkisi nedeniyle gıdada meydana gelen deformasyon, kırılma ve mikro yapısal değişikliklerle ilgilenmektedir (Lillford, 2011; de Lavergne ve ark. 2017). Oral fizyoloji, çene hareketi, tükürük salgılanması, dilin kayma hareketi, dilin damak üzerine uyguladığı baskı, orofasiyal bölgedeki kaslar ve ağız boşluğunda bulunan mekanoreseptör ve termoreseptör gibi reseptörlerin uyarılması gibi gıdanın ağıda fiziksel olarak işlenmesi sırasında ağız boşluğunda meydana gelen çeşitli tepkiler ve değişiklikler ile ilgilenmektedir (Foegeding ve ark. 2011; Carpenter ve Blissett, 2017).

Duyusal psikoloji, nörolojik sistem tarafindan verilen geri bildirim mekanizmalarının yardımıyla ağızdaki hislerin algılanması ve duyusal özelliklerin belirlenmesini hedef almaktadır (Goldstein, 2009; Spence, 2011). Duyusal psikoloji alanındaki son çalışmalar, duyusal uyaran ve beyin sinyalleri arasındaki ilişkiyi anlamak için nörolojik yönlere odaklanmaktadır (Oatley, 2017). Beyindeki "geri bildirim yolları" ile ilgili fonksiyonel manyetik rezonans görüntüleme kullanılarak çiğneme ve tekstür algısı üzerine belirlenen aktivasyonları açıklayan az sayıda çalışma bulunmaktadır (Liu ve ark. 2000; Quintero ve ark. 2013; Francis ve Eldeghaidy, 2015). Fakat bununla birlikte, daha önceki çalışmaların bazıları, sert ve yumuşak katıları deforme etmek için gerekli otomatik kontrol sinyallerine daha fazla

31 | P a g e

www.iiste.org 
odaklanması gerektiğini bildirmektedir (Onozuka ve ark. 2002; Takahashi ve ark. 2007). Yiyeceklerin ağızdaki sindirimi genel olarak, mekanik olarak parçalanması, kolloidal destabilizasyon ve biyokimyasal ve enzimatik interaksiyon olarak üç mekanizma ile yönetilmektedir. Bu mekanizmalar, gıdaların ağızda işlenmesi sırasında eş zamanlı olarak ortaya çıkmaktadır (Chen, 2015) (Şekil 2). Mekanik olarak parçalanma; katı gıdaların ağız boşluğunda mekanik olarak parçalanması, uzunluk ölçeğinde boyutlarının küçülttülmesi (santimetre ölçeğinden milimetreye hatta mikrometre ölçeğine) ve yutulabilir bolus kıvamına ulaşılana kadar tükürük ile sürekli ıslatma anlamına gelmektedir. Yarı katı ve viskoz sıvı gıdalar, ağızda işlenmesi sırasında genellikle 1sıtma, kesme, kimyasal bozulma ve viskozitede azalma gibi çeşitli oral değişikliklere uğramaktadırlar. Bununla birlikte, yüksek viskoz sıvılar ve yarı katı gıdalar, zaten yutulabilir formda oldukları için çiğnemenin ya çok az ya da bu döngünün hiç olmadığ 1 belirtilmektedir (Prinz ve ark. 2007). Mekanik deformasyon ve tekstürel özellikler; tat ve aromanın salınımı, yutulan gıdaların çeşitli duyusal olgularının algılanmasını kolaylaştırmaktadır (Funami, 2017; Liu ve ark. 2017).

Yiyeceklerin mekanik işleme uğratılması, ağız boşluğunun birkaç kısmı tarafindan yapılan çeşitli hareketler ve kuvvetler ile gerçekleşmektedir. Bu çiğneme, çenelerdeki dişlerle (kesici dişler kesmeye yardımcı olur, köpek dişleri yırtılmaya, azı dişler ve küçük azı dişleri ise iyi öğütmeye yardımcı olur) 1sırma hareketini ve belirli kayma hızları ve dilin damağa uyguladığı kuvvetleri içermektedir. Tüm katı gıdalar (hem sert hem de yumuşak katılar) çiğneme (ısırma ve çiğneme) ile partikül büyüklüğünü azaltarak tükürük ile birleştirilmekte, yumuşak ve yutulabilir bir bolus/lokma oluşturmakta ve böylece, tükürük yardımıyla mekanik parçalama işlemi, akıcı olmayan katı yiyecekleri akıcı bir bolusa dönüştürmektedir. Bu durum gıdaların sindirim için yemek borusundan mideye taşınmasına yardımcı olmaktadır. Gıdalarda tekstür algısı çok önemlidir, çünkü dinamiktir ve gıdanın ağızda işlenmesi sırasında gerçekleşmektedir. Ağızda işlenmenin ilk aşamasında, gıdaların deformasyonu ve kırılması meydana gelmekte ve tekstür algısı böylece reolojik bir sistem olarak karakterize edilmektedir. Sonraki aşamalarda ise, tekstür algısı büyük ölçüde gıda-dil, gıda-dil-damak ve dil-damak arayüzleri, tükürüğün kayganlaştırma etkisi, gıdaların yüzey özellikleri ve ağızdaki yüzeyler arasında sürtünmeye ve aşınmaya bağlı olarak gerçekleşmektedir. Bu nedenle, bu daha çok reolojinin değil tribolojinin ilgili olduğu bir konu haline gelmektedir (Chen ve Stokes, 2012).

Tükürük, tükürük bezleri tarafından salgılanan \%99'u sudan, \%1'lik kısım ise, elektrolitler, proteinler, enzimler, karbonhidratlar vb. gibi moleküllerden oluşan tatsız ve renksiz olarak tanımlanan biyolojik bir sividır (Wang ve Chen, 2017). Yutulan gidalar, öncelikli olarak tükürük ile temas etmekte ve bu da tükürüğü ağızda fiziksel olarak işlemede ve tekstür algısında vazgeçilmez bir bileşen haline getirmektedir. Ayrıca, gıdanın tükürük ile etkileşimi ve tükürüğün varlığına bağlı olarak ortaya çıkan kolloidal destabilizasyon ağızda hissedilen bazı özellikleri belirgin bir şekilde etkilemektedir (Mosca ve Chen, 2017). Örneğin, emülsiyonların koloidal destabilizasyonu, kremsilik (Disckinson, 2018), burukluk (García-Estévezve ark. 2018), ve kayganlık gibi yağlı yapı algıları gibi çeşitli ağızda hissedilen özelliklerin algısı üzerinde birçok etkisinin olduğu belirtilmiştir (Dickinson, 2018; Guichard ve ark. 2018). Gıda emülsiyonlarının ağızda destabilizasyonu; tuzla indüklenen agregasyon, birleşme, ağızda biçimlendirme ve tükürük ile birleştirilmesi sonucu meydana gelen bağlama flokülasyonu olmak üzere dört temel mekanizma ile açıklanmıştır (Sarkar ve Singh, 2012; Mosca ve Chen, 2017). Genel olarak, iyi dağılmış bir emülsiyon pürüzsüz veya kremsi bir ağız hissine sahip olarak ve destabilize olmuş bir emülsiyon pürüzlülük/kuruluk gösteren tamamen farklı bir tekstür algısı meydana getirmektedir (Schipper ve ark. 2007). Bazı durumlarda ise emülsiyonlar, aşırı derecede yağ damlacıklarının birleşmesinden dolayı yağlı veya kaygan bir ağız hissi gösterebilmektedir. Burukluk, kayganlaşmayı sağlayan protein müsinin (glikoprotein) azalması ile oluşan sürtünme (azaltılmış yüzey yağlama) nedeniyle algılanmaktadır. Kayganlaştırmanın azalması ise, tükürük proteininin tanenler ve polifenoller ile birikmesiyle oral kolloidal destabilizasyondan kaynaklanmaktadır (Gibbins ve Carpenter, 2013).

32 | P a g e 


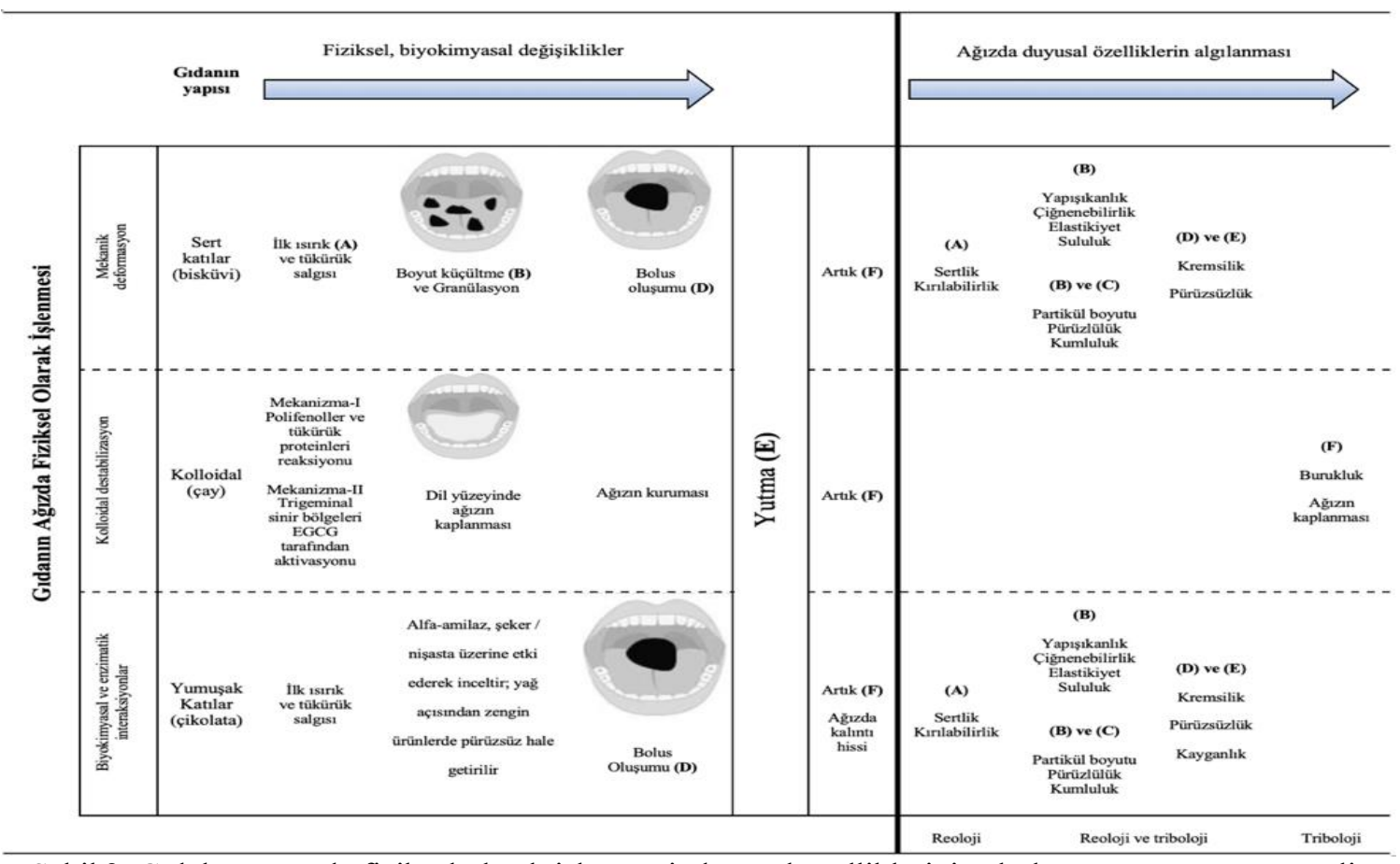

Şekil 2. Gıdaların ağızda fiziksel olarak işlenmesi, duyusal özelliklerinin algılanması ve ağızın önemli kısımları arasındaki ilişki (Sethupathy ve ark. 2020)

Tükürük iki ana enzimden oluşmaktadır, $\alpha$-amilaz ve lingual lipaz enzimi hem ağızda duyusal özelliklerin algılanması hem de nişasta ve lipitlerin sindirimi için oldukça önemlidir. $\alpha$-amilaz genellikle yutulan gıdada bulunan nişasta molekülleri üzerinde etki olmaktadır. Daha küçük maltoz şekeri molekülleri oluşturmak için amiloz ve amilopektin bağlarını hidrolize ederek ( $\alpha$ 1-4) nişasta moleküllerini parçalamaktadır. Nişasta bakımından zengin bir yiyecek ağızda işlenirken ve tükürük ile temas ettiğinde, viskoz gıdalar da yiyeceklerin ağızda incelmesi ve şekerlerin oluşumu nedeniyle tatlı bir tat algısı oluşmaktadır. Birçok çalışma, nişastalı veya şekerli gıdaların ağızda inceltilmesini açıklamaktadır. In vitro mekanik ağız simülatörleri, mekanik olarak parçacık boyutunu küçültmekte, tükürük ile karıştırma, bolus oluşumu, çene kasları tarafindan uygulanan kuvvetler, dil hareketi (toplama mekanizması), ve ağızda hissedilen duyularının geri bildirim mekanizması gibi ağızda işleme faaliyetlerini taklit etmek için geliştirilen cihazlar şeklinde oluşturulmaktadır (Bridges ve ark. 2017; Peyron ve ark. 2018).

Tekstür özellikleri, belirli doku özelliklerini değerlendirmek için eğitimli panelistler tarafindan duyusal analiz teknikleriyle en doğru şekilde ölçülmektedir (Foegeding ve Drake, 2007). Gıda tekstürü, gıdaların yapısal, mekanik ve yüzey özelliklerinin duyusal ve işlevsel bir sonucudur ve gıdalardaki tat, aroma ve doku algısı, nefes alma, çiğneme, tükürme, yutma, sıcaklık değişimleri ve dil hareketlerinin doğas1 nedeniyle dinamik bir durumdur (Dijksterhuis ve Piggott, 2001). Bu, tekstürün yiyeceğin mekanik veya reolojik özellikleri ile sınırlı olmadığını açıklamaktadır. Sıvı gıdaların tekstürü, akış hızı gözlemlenerek görsel olarak değerlendirilebilir; örneğin, sadece gözlem yoluyla, balın meyve suyundan daha viskoz olduğu sonucuna varılabilmektedir. İşitsel duyular ayrıca, yiyeceklerin ilk ısırık sırasında ürettiği sese dayanarak gıdaları ayırt etmede ve tanımlamada bize rehberlik edebilmektedir. Ayrıca, tekstür-duyu iletişimi bize gıda kalitesi hakkında da bir fikir verebilmektedir. Esasen duyusal tekstür analizi oldukça karmaşıktır, çünkü ağıza alınan gıda maddesi kısa sürede birçok işleme maruz kalmakta ve değişime uğramaktadır. Bunlar arasında; ön dişlerle kesme, çiğneyerek öğütme, ağız salgısında bazı maddelerin çözünmesi ve birtakım uyarıcıların (örneğin, tuz, şeker, aroma, tat ve koku bileşenleri vb.) ortama salınması ve sonra yutma sayılabilir. Tüm bunların aletsel olarak aynı anda taklit edilmesi kolay bir iş değildir (Szczesniak, 2002).

Tekstür, uzun zamandan bu yana başta aroma olmak üzere çoğu zaman diğer duyusal gıda özelliğinin

33 | P a g e

www.iiste.org 
gölgesinde kalmıştır. Ancak 1960'larda ve 1970'lerde, Alina Szczesniak (1990) gıdaların tekstürel özelliklerin belirlenmesini popülerleştirmeye başlayınca önem kazanmaya başlamıştır. $\mathrm{Bu}$ süre içerisinde gıda endüstrisinde, yeni ürünlerin tüketiciler tarafindan kabul edilmesinde tekstürün önemi anlaşılmaya başlamıştır. Dokunsal hislerin vücut ve gıda arasındaki temasından kaynaklanan, fiziksel uyarılara verdiği yanıt olarak tekstür, aynı zamanda, somatosensoriyel (tat tomurcukları etrafında bulunan sıcaklık, ağrı, tahriş gibi duyuları hissetmemizi sağlayan nöronlar) temas alanı ile sınırlı değildir, çünkü kinestez (hareketlerin beyin tarafından algılanması) ve çiğneme sırasında da tekstür bilgileri şekillenmektedir. Ayrıca tekstür, gevreklik ve tazelik gibi özelliklerde işitme duyusuyla da önemli bir rol oynadığı için sadece dokunmayla sınırlı olmayan ve görme, akış hızı, çökme derecesi gibi parametreler hakkında da bilgi sağlayabilmektedir (Bourne, 2002; Simon ve ark. 2006; Engelen ve Van Der Bilt, 2008). Ağız boşluğundaki duyusal tekstür özelliklerinin algılanması, bir kişinin belirli bir gıdayı ne kadar sevdiğinin önemli bir belirleyicisidir ve bu nedenle de bir bireyin beslenme durumunu doğrudan etkileyecek yiyecek tercihini belirlemede de gıdanın tekstürü önemli olabilmektedir (Mioche ve ark. 2004). Bununla birlikte insanlar gıdaları tüketirken birçok nedenden dolayı farklı çiğneme hızı kullanmaktadır ve kişinin fizyolojik durumu, ağız ve diş sağlığı, duyusal durumu gibi hususlar konuyu daha karmaşık hale getirmektedir (Chen ve Stokes, 2012; Ozcan ve Baysal, 2018).

Flavor, yemek yerken ve içerken sahip olduğumuz algısal deneyim anlamına gelmektedir. Aynı zamanda, beslenme ve solunum yollarının girişinde birlikte gruplandırılan duyu uçlarının uyarılmasından kaynaklanan tat ve koku algılarının toplamı olarak tanımlanmaktadır. Duyusal bilimde, flavor genellikle ağızdaki bir üründen kimyasal duyular yoluyla algılanan izlenimler olarak nitelendirilmektedir. Gıdanın flavor algısı, koku alma, tat alma, mekanik, trigeminal ve hatta işitsel kaynaklar da dahil olmak üzere farklı duyusal kanallardan gelen sinyallerin birleşerek bütün bir duyusal algı oluşturduğu çok boyutlu bir etkileşimi içermektedir (Simon ve ark. 2006; Stevenson, 2009).

Koku alma, ortonazal ve retronazal kokuları tanımlamamıza izin veren duyu özelliğidir (Negoias ve ark. 2007) (Şekil 3) ve koku alma işlemi, koku veren mukoza ile bir koku verici madde temas ettiğinde başlamaktadır. Koku algısı, burun boşluğunu kaplayan ana koku alma epitelinde bulunan koku alma duyu nöronları tarafından açığa çıkan reseptörlerin aktivasyonu ile başlamaktadır. Her koku alma duyu nöronları, epitelyumun lümenal yüzeyine tek bir dendrit olarak uzamakta, buradan da hareketsiz kirpikler kokuları yakalamak için uzanmaktadır. Bu koku alma duyusundaki kirpikler, koku verici reseptörlerde ve hücredeki ilk transdüksiyon olaylarına aracılık eden diğer sinyal bileşenlerinde zenginleştirilmektedir. Nöronun diğer ucunda, koku alma soğancığına tek ve dalsız bir akson olarak yansıtılarak gerçekleşmektedir (Firestein, 2001). Çalışmalar, kimyasal yapıdaki benzer kokuların beynin benzer bölgelerindeki nöronları aktive ettiği gözlemi nedeniyle beynin bir çeşit kemotropik organizasyona sahip olabileceğini düşündürmektedir (Wilson, 2001; Leon ve Johnson, 2003). Koku alma sistemi dinamiktir ve çevreye duyarlı olmaktadır. Spesifik koku alma sinyalleri belirli koku kaynaklarına bağlı olarak kabul edildiğinde davranışsal önem kazanmaktadır (Sicard, 2002).

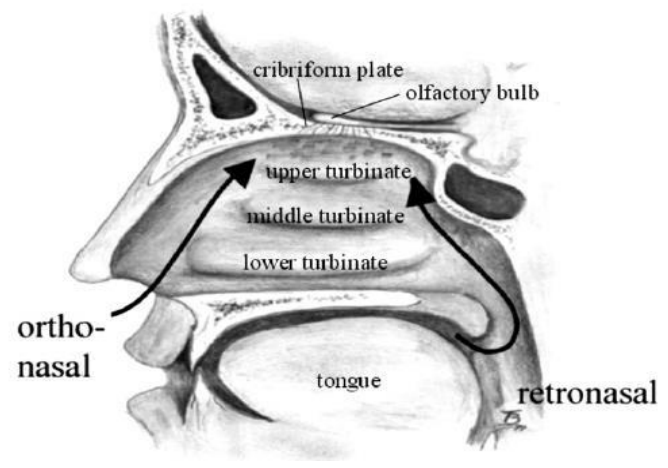

Şekil 3. İnsan burun ve ağız boşluğunun anatomisi (Negoias ve ark. 2008)

Tat alma, koku alma gibi gibi kimyasal bir duyudur. Tat, tat tomurcukları içindeki reseptörler tarafindan su, yağ veya tükürükte çözünmüş uyaranların tespit edilmesi ile oluşmaktadır. Tat verici moleküller

34 I P a g e

www.iiste.org 
(doğrudan ya da dolaylı olarak) ağızdaki tat alıcı hücrelerinin zarlarındaki, tat tomurcukları şeklinde organize edilmiş olan iyon kanallarına bağlanmakta ve sinyal dönüştürülmektedir. Daha sonra transdüksiyon olarak bilinen bir süreçte beyne gönderilmektedir (Chandrashekar ve ark. 2006). Yediğimiz yiyecekleri daha iyi karakterize etmemizi sağlamakta ve genel olarak tatlı, ekşi, acı, tuzlu ve umami olmak üzere 5 farklı tat grubu ile tanımlanmaktadır (Stevens ve ark. 2006). Tatma bileşikleri, ağız boşluğunda, esas olarak dil üzerinde, aynı zamanda yutak, epiglot (küçük dil), grrtlak ve yumuşak damak üzerinde yaklaşık 5000 tat tomurcuğu tarafindan algılanmaktadır. Tat tomurcukları, 50-100 farklı özel tat reseptör hücresi içeren soğan şeklindeki yapılardır. Bu tat reseptör hücrelerinin membranı, tükürükte çözülmüş çeşitli tat moleküllerini algılayabilen spesifik tat dedektörlerini içermektedir. Dilin tat tomurcuklarında fungiform, foliate, ve circumvallate papillalar olmak üzere üç tip papilla bulunmaktadır (Şekil 4). Tat reseptör hücreleri, ultrastrüktürel özelliklere, protein markerlarına ve farklı fonksiyonlara dayanarak Tip I, Tip II ve Tip III hücreleri olarak adlandırılan üç ana sınıfa ayrılmaktadır. Tip I hücreleri tuzlu tad algılanmasında Tip III reseptör hücreleri ekşi tat, Tip II reseptör hücreleri ise, umami, tatlı ve acı tadın algılamasında etkili olmaktadır (Briand ve Salles, 2016).

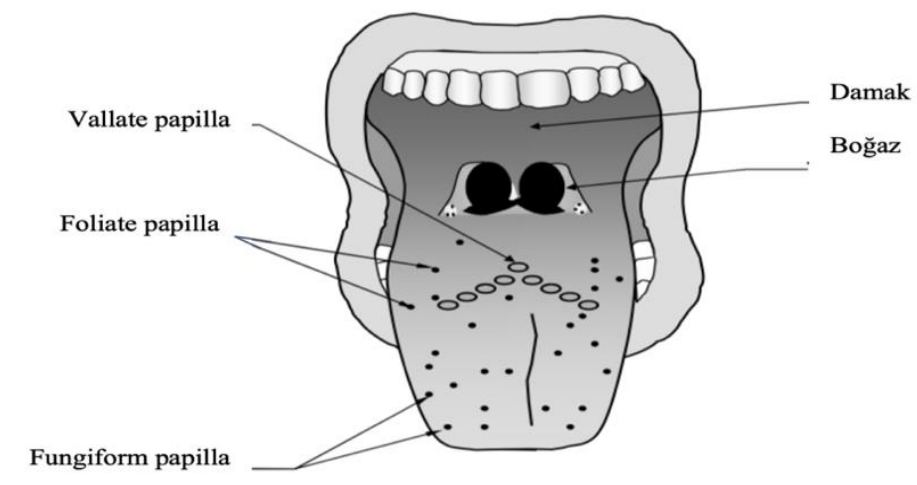

Şekil 4. Ağız boşluğu ve dil üzerindeki tat papillaları (Tournier ve ark. 2007)

Chemesthesis (cilt ve mukus membranlarının kimyasal duyarlllığl), flavor algısında önemli bir faktördür, ancak genellikle tat ve koku ile gölgelenmektedir. Chemesthetic duyuların, birçok yiyeceğin genel kabulüne katkıda bulunduğununun saptanması bu duyguyu flavorun ötesine geçirmektedir. Chemesthesis, deride bulunan kimyasal bileşikler termal, ağr1 ve dokunma reseptörlerini aktive ettiğinde algılama başlamaktadır (Carstens ve ark. 2002). Acı biberle yanma, karbonatlaşma ile karıncalanma ve nane keskinliğinin soğukluğu "kimyasal chemesthetic özellikler" olarak tanımlanmaktadır. Yaban turpu, zencefil, amonyak, mentol ve soğan gibi kimyasal tahriş ediciler, ağız, burun ve gözlerin mukoza zarlarındaki serbest sinir uçlarını uyarmaktadır (Ross, 2009). Burun ve ağızda, bu genel kimyasal duyarlılı̆ga trigeminal sinirlerin aracılık ettiği bildirilmiştir. Bununla birlikte, chemesthetic yanıt genellikle bir koku alma veya tat alma tepkisi ortaya çıkarmak için gerekenden çok daha yüksek konsantrasyonlarda maddeyi gerektirmektedir (Meilgaard ve ark. 2007).

\section{Tekstür - Flavor Etkileşimleri}

Yiyeceklerin ve içeceklerin tekstürel özelliklerinin flavor algısını etkilediği bazı araştırmacılar tarafindan belirtilmiştir (Buettner ve ark. 2001; Repoux ve ark. 2012; Luckett ve ark. 2016). Araştırmalarda, çiğneme modelinin, tekstürel özelliklerin ağızdaki flavor algısını nasıl etkilediğini anlamada önemli bir faktör olduğu ortaya konulmuştur (Buettner ve Schieberle, 2000; Mestres ve ark. 2006; Repoux ve ark. 2012; Luckett ve ark. 2016). Çiğneme sırasında tekstürün algılandığı farklı aşamalar; (i) Başlangıç (ilk ısırma); (ii) çiğneme ve (iii) kalıntı (artık) (çiğneme sırasında tekstür) olarak tanımlanmıştır (Foegeding ve Drake, 2007). Çiğnemenin bu üç faza ayrılması, çiğneme sırasında gıdaların özelliklerini yakalamaya çalışan in vitro tekniklerin gelişimini engellediğinin belirlenmesi ile, katı gıdaların rasyonel tasarımını mümkün kılan in vitro yaklaşımlar geliştirmek amacıyla, çiğnemenin 6 aşamaya ayrılması önerilmiştir; (i) ilk ısırma, (ii) parçalama, (iii) granülasyon, (iv) bolus oluşumu, (v) yutma ve (vi) kalıntı (Şekil 5). Bu anlamda, gıdanın değişen durumu her aşamada incelenmekte olup, bunları ayrı ayrı değerlendirmek, altta yatan fiziğin anlaşılmasını sağlamakta ve böylece gıda

35 | P a g e

www.iiste.org 
bileşenlerinin spesifik işlevselliği hakkında da daha fazla bilgi edinilebilmektedir (Stokes ve ark. 2013).

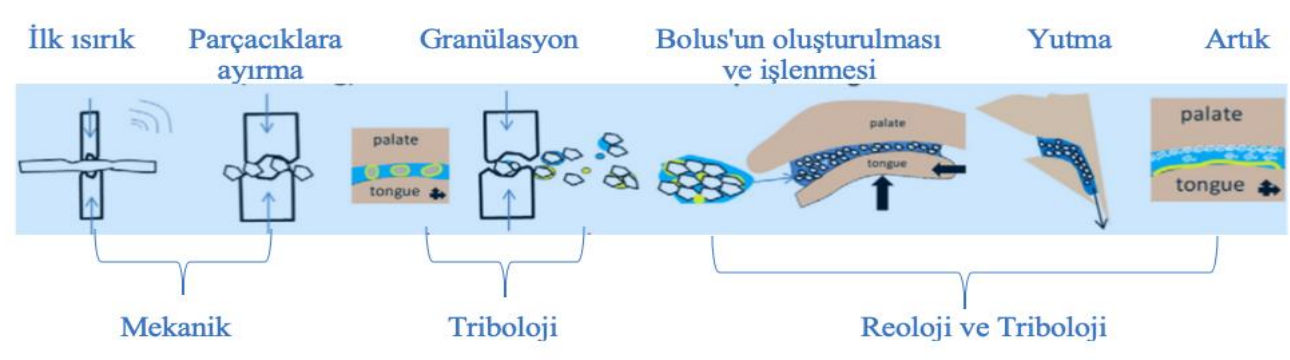

Kırılgan katılar için baskılayıcı his $\longrightarrow$ sıvılar ve yumuşak katılar için tekstür / ağız hissi

\begin{tabular}{|c|c|c|c|c|c|}
\hline gevreklik & citırlik & pürüzlü & yapıskan & pürüzsüz & $\ldots$. \\
\hline
\end{tabular}

Şekil 5. Katı gıdaların çiğnenmesi sırasında önerilen 6 temel aşama (Stokes ve ark. 2013)

Daha spesifik olarak, çiğneme şeklinde, tesktürel özelliklerde meydana gelen değişiklikler, gıda matriksinden salınan aromatik salınım kinetiklerini değiştirerek, gıda bolusunun fiziksel özelliklerini modüle edebilen çok çeşitli varyasyonlarla sonuçlanmaktadır (Buettner ve Schieberle, 2000; Harrison, 2000; Salles ve ark. 2011). Ayrıca, tekstürel özelliklerin flavor algısı üzerindeki etkisinin arkasında daha etken psikolojik bir mekanizma olduğunu gösteren çalışmalar da bulunmaktadır. Örneğin, aroma algısının, gerçek aroma uçucu bileşiklerinin konsantrasyonundan bağımsız olarak değiştiği de saptanmıştır (Weel ve ark. 2002; Leclercq ve Blancher, 2012). Gierczynksi ve ark. (2008) sık1 jellerin parçalanması için fazla çaba sarf edildiğini ve böylece çiğneme sırasında gıdanın tekstürel özelliklerine daha fazla dikkat çekildiğini, bu da jellerin diğer yönlerine, özellikle aromalarına verilen dikkati sinırlandırdığı sonucuna varmışlardır.

Önceki çalışmalar, gıda tekstürünün çiğneme davranışını etkilediğini göstersede, nispeten az sayıda çalışma, çiğneme modellerindeki değişikliklerin geçici flavor dinamiklerini ve genel flavor algısını nasıl etkileyebileceğini doğrudan ele almaktadır (Blissett ve ark. 2006; Tarrega ve ark. 2008). Tarrega ve ark. (2008), Zaman-Yoğunluk (TI) analizinde çiğneme ve çiğneme gücünün peynirlerde maksimum flavor yoğunluğu (Imax) ile pozitif korelasyon gösterdiğini, çiğneme süresinin ise maksimum flavor ile negatif korelasyon gösterdiğini göstermişlerdir. Yapılan benzer bir araştırmada, sade, peynirli ve baharatlı patates cipslerinin gevreklik seviyesinin, (üç yaş grubuna göre genç (20-25 yaş), orta yaşlı (40-45 yaş) ve daha yaşlı (65+ yaş)) algılanan flavor yoğunluğu ile zamansal olarak etkilenip etkilemediğini belirlemek amacıyla çalışılmış, patates cipsi yerken, katılımcıların çiğneme modeli de elektromiyografi (EMG) ile değerlendirilmiştir. Zaman-Yoğunluk analizi, patates cipsinin gevrekliği arttıkça aromaların daha yoğun derecelendirildiğini ve maksimum aroma algısının daha hızlı gerçekleştiğini göstermiştir. Orta dereceli çiğneme kuvvetinin, daha taze örneklerde daha fazla olduğu saptanırken ve flavor derecesine bakılmaksızın, genç katılımcılar yaşlı yetişkinlerden daha kısa çiğneme süreleri sergilemişlerdir. Sonuç olarak yapılan bu çalışmada, tekstürel özelliklerin sıvı ve yumuşak gıdalardaki flavor algısının gevrek/kırılgan gıdaları da etkileyebileceğini göstermişler ve ayrıca gevreklik düzeyinin flavor algısı üzerindeki etkisi flavor çeşidine, yaş grubuna ve çiğneme şekline göre değişebileceği saptanmıştır (Luckett ve ark. 2016).

Öte yandan, çiğnemenin şekerdeki flavor salımı üzerindeki etkisini gözlemleyen diğer araştırmacılar, yavaş çiğneme oranı ve düşük ısırma kuvveti sergileyen panelistlerin, daha hılı çiğneyenlere göre daha fazla uçucu flavor salınımı sergilediğini bildirmiştir. Bu nedenle, aroma salınımı ve algısındaki sonraki değişikliklerle ilgili özel çiğneme davranışlarının ne olduğunu tam olarak anlamak için daha fazla araştırmaya ihtiyaç olduğu belirtilmiştir (Blissett ve ark. 2006). Tekstürün, özellikle flavor olmak üzere gıda algısının diğer yönlerini de etkileyebileceği iki mekanizma bulunmaktadır. Birincisi, aroma salınım kinetiğindeki değişikliklerden, ikincisi ise çok boyutlu entegrasyondan kaynaklanmaktadır. Gıdanın tekstürü ve flavor arasındaki ilişkiyi inceleyen model sistemlerde, gıda viskozitesi arttıkça aroma salınımının azaldığı görülmüştür (Cayot ve ark. 2004; Terta ve ark. 2006). Ayrıca, sıvılarda ve

36 | P a g e

www.iiste.org 
yarı katı gıdalarda da viskozitedeki artış ile birlikte flavor algısının baskılandığı bildirilmiştir (Kremer ve ark. 2005).

Repoux ve ark. (2012) katı gıdalarda belirtilen eğilimi gözlemlemişlerdir; peynir sertliğindeki artış, salınan aroma oranını ve miktarını arttırmıştır. Bununla birlikte araştırmacılar, peynir dokusundaki değişikliklerin, tükürük verimini ve çiğneme süresini değiştirerek tekstür ve flavor algısı arasında dolaylı bir ilişki oluşturabileceğini de işaret etmişlerdir. Cook ve ark. (2005), biberiye aroması algısı ile aroma salınımı arasında yüksek bir korelasyon olduğunu göstermek için gerçek zamanlı kütle spektroskopisini (MS-Nose) kullanmışlardır. Bir gıda matriksinden salınan uçucu bileşiklerin ölçülmesi, flavor algısını belirlemede yararlı olduğu gibi, tekstür korelasyonunda flavor algısına etkisinin dikkate alınması gerektiği belirtilmiştir. In vivo flavor salımının da ayrıntılı olarak anlaşılması, gıda bileşimi ve yapısında algılanan flavor üzerindeki rolünü anlamak için bir anahtar olmaktadır.

Tekstürün gıdanın duyusal algısının diğer özellikleri üzerindeki ilişkisi, bu gıdaları tüketme eğilimleri incelendiğinde kolayca anlaşılabilmektedir. Daha önce de belirtildiği gibi, çiğneme işlemi gıda tekstürüne, gıda tekstürünün algısı da çiğneme sürecine bağlı olmaktadır. Ek olarak, ağız boşluğunda gıda matriksinin değiştirilme şekli, uçucu flavor bileşiklerinin nasıl salındığını ve tat moleküllerinin dil üzerindeki tat reseptörleriyle nasıl etkileşime girebileceğini doğrudan etkilemektedir. Birçok çalışma, gıdanın tekstüründeki değişikliklerin tat ve koku algısını nasıl etkilediğini karakterize etmeye çalışmıştır. Bu çalışmalardan insan flavor algısının gıda tekstüründen nasıl etkilenebileceğini belirleyen üç ana faktör bulunmaktadır. Birincisi, yapıdaki farklılığın ve deformasyon derecesinin çiğnemede değişikliklere yol açabildiği ve çiğneme değişikliklerin de aroma bileşiklerinin gıda matriksinden nasıl salındığını belirlemesidir (Harrison, 2000; Salles ve ark. 2011). İkincisi, yutma ve burun hava akışı, burun boşluğunda koku alma reseptörleri ile temas eden koku bileşiklerinin konsantrasyonunu belirlemektedir (Buettner ve Schieberle, 2000; Harrsion, 2000; Buettner ve ark. 2001). Üçüncü olarak, farklı flavor bileşikleri farklı salınım kinetiklerine sahip bulunmaktadır. Özellikle, hidrofilik bileşikler çiğneme işleminin başlarında en yüksek miktarlarda salınırken, daha hidrofobik bileşikler yutulduktan sonra genellikle yüksek bir değer göstermektedir (Repoux ve ark. 2012). Çiğneme değişiklikleri ve tekstür-flavor etkileşimlerinin korelasyonunu tam olarak anlamak için ağızdaki mekanizmaların ve süreçlerin etkisinin incelenmesi gerekmektedir (Buettner ve ark. 2001; Trelea ve ark. 2008).

Gıdanın tekstürü ile aroma salınım kinetiğindeki değişikliklere ilişkin önemli kanıtlar olmasına rağmen, temel olarak bilginin beyine entegrasyonu gibi alternatif kaynaklar gösteren çalışmalar da bulunmaktadır. Tam mekanizma ve sinirsel yakınsaklık ortaya çıkarılamamıştır, ancak tekstür-flavor sinirsel entegrasyonuna işaret eden birkaç psikofiziksel olay bulunmaktadır (Weel ve ark. 2002; Leclercq ve Blancher, 2012). Leclercq ve Blancher (2012) katılımcıların flavor algısında bir azalma ile birlikte burun boşluğunda aroma bileşiklerinde artış olması durumunda çiğnenebilir şekerlemede tekstürün aroma algısı ile çapraz-model etkileşimini gözlemlemişlerdir. Aroma bileşiklerinin burun içi konsantrasyonunun, toplam flavor algısının sadece bir parçası olduğu ve bir gıdanın tekstür-flavor ilişkisini tahmin etmeye çalışan modellerde tek faktör olamayacağ araştırmada, örnekler sırasıyla verildiğinde, adaptasyon ve kontrast etkilerinin ortaya çıkması, tekstür flavor algısı üzerindeki etkiyi işaret etmiştir (Leclerq ve Blancher, 2012).

Burseg ve ark. (2011) elma suyunun viskozitesi arttıça, algılanan tatlılık yoğunluğunda bir azalma gözlemlememişlerdir. Bununla birlikte, gözlenen viskoziteye bağlı tat baskılama konusunda başka teoriler de belirtilmiştir. Belirli tatlandırıcılara bağlanabilen hidrokolloidler ekleyerek viskoziteyi değiştirmek oldukça yaygın çalışılan bir yöntem olarak tanımlanmıştır. Flavor ve tadın baskılanmasının hidrokolloidlerin çeşidinden bağımsız olduğu hipotezi de ortaya konmuştur (Hollowood ve ark. 2002; Weel ve ark. 2002; Cook ve ark. 2005; Ferry ve ark. 2006). Başka bir teori ise tekstür-flavor etkileşimlerinin gıdaya özgü olabileceği, yani bir gıdada meydana gelirken ve başka bir gıdada bulunmayabileceği düşünülmektedir. Kremer ve ark. (2007b), tatlı waffle için bir tekstür-flavor etkileşiminin gözlemlendiğini, ancak peynir aromalı wafflelarda bunun saptanmadığını belirtmişlerdir. Tatlı sadece bir tat iken, peynir aroması ise peynir aroması kavramı için ayrılmaz güçlü bir retronazal koku özelliğine sahip bulunmaktadır.

Peynirdeki aroma gelişimi peynirin olgunlaşması sırasında meydana gelmekte ve bu profil glikoliz, lipoliz ve proteoliz olmak üzere üç ana katabolik yolu içeren karmaşık bir süreç sonucunda oluşmaktadır ve temelde de değişimler tekstür özelliklerinde ortaya çıkmaktadır. Süt ürünlerinde süt yağı ve lipoliz peynir kalitesinde tat, aroma yapı ve teknolojik özellikler için önemli bir unsurdur. Süt

37 | $P$ a g e

www.iiste.org 
yağı protein ağına esneklik kazandırarak peynirin tekstürü üzerine etkili olurken, hidrolizi sonucu ortaya çıkan serbest yağ asitleri olgunlaşmış peynirlerin aroması üzerinde etkili rol oynamaktadır. Özellikle, kısa zincirli serbest yağ asitleri (10,0 zincirliye kadar) süt ürünlerinin tat ve aromalarının oluşmasında önemli bir etkiye sahip bulunmaktadırlar (Ozcan ve Baysal, 2018). Yoğurttaki aromanın algılanması ise, yoğurt jelinin bileşimi, kolloidal ve reolojik özelliği ve ayrıca laktik asit bakterilerinin fermantasyonu ile sütte meydana gelen biyokimyasal reaksiyonlar sonucunda oluşmaktadır (Soukoulis ve ark. 2012).

\section{Tat - Aroma Etkileşimleri}

Çapraz-model etkileşimler arasında tat-aroma etkileşimleri yaygın olarak incelenmiştir. Genel olarak, tat ve aroma bileşikleri eşik veya eşik altı konsantrasyonlarda olduğunda ortaya çıkabilmektedir ve incelenen g1da matriksine bağlı olmaktadır (Lethuaut ve ark. 2005; Labbe ve ark. 2007; Labbe ve Martin, 2009; Marks ve ark. 2012). Aromanın tat algısı üzerinde çeşitli etkilerinin olabileceği ve aromanın algılanabilmesi için de gıda tüketilirken aroma bileşiğinin gıdadan serbest kalması gerektiği belirtilmektedir. Boakes ve Hemberger (2012), bir aromanın bir tat algısını maskeleyebileceğini açıklamaktadır (örneğin, bir 'karamel' aroması ekşiliği maskelemektedir). Diğer durumlarda, aromanın tat yoğunluğuna herhangi bir etkisinin olmadığ 1 da belirtilmektedir (örneğin 'elma' aroması tatlılık algısını etkilememiştir) (Lethuaut ve ark. 2005). Aroma aynı zamanda tat algısını da arttırabilmektedir. Vanilya, karamel veya çeşitli meyveli aromalar tatlılığı arttırırken (Labbe ve ark. 2006; Tournier ve ark. 2009; Burseg ve ark. 2010; Boakes ve Hemberger, 2012), kakao aroması acı tadı arttırmaktadır (Labbe ve ark. 2006). Bununla birlikte et, balık ve peynir gibi gıdalar geliştirilmiş tuzluluk algısını geliştirmektedir (Lawrence ve ark. 2009; Nasri ve ark. 2011). Tadın aroma algısı üzerindeki etkisi ile ilgili olarak, değişken etkiler de vurgulanmıştır. Örneğin, tatlılıkla farklı 'meyveli' aromaların yoğunluğunda bir artış saptanırken (Hort ve Hollowood, 2004; Lethuaut ve ark. 2004; Tournier ve ark. 2009), tuzluluk ile 'mantar' aroması yoğunluğunun arttığı (Ventanas ve ark. 2010a,b) ve ekşiliğe göre de 'limon' aroma yoğunluğunda da bir artış ortaya çıktığ 1 belirlenmiştir (Hewson ve ark. 2008). Boakes ve Hemberger (2012), sitral bir aromanın, tatlılığı arttırırken çözeltilerin ekşiliğini azalttığını ortaya koymuştur.

Genel olarak, bu veri farklılı̆gı, öngörülemeyen fiziko-kimyasal, fizyolojik ve psikolojik mekanizmalardan kaynaklanan bu etkileşimleri karakterize eden çeşitlilikten ortaya çıkmaktadır. Fiziko-kimyasal mekanizmalar, örneğin tat bileşenleri ile uçucu bileşikler arasındaki kimyasal ve fiziksel etkileşimleri içermektedir. Bir matriks içinde bazı tat bileşiklerinin varlı̆̆ bileşiklerin değişimi, molar konsantrasyonunu ve su aktivite katsayısını etkileyebilmektedir. Bu, tepe boşluğu gaz kromotografisi kütle spektroskopisinde (Headspace Gas Kromotografi Mass Spectrometry) tepe boşluğunda uçucuların azalmasına, artmasına veya sabit bir konsantrasyonda kalmasına neden olmaktadır (Saint-Eve ve ark. 2009). Ayrıca, bir tat bileşiğinin eklenmesi, bazı durumlarda, matriks yapısında bir değişikliğe de yol açabilmektedir (Hewson ve ark. 2008; Siefarth ve ark. 2011; Heenan ve ark. 2012). Daha sonra matriks boyunca uçucuların difüzyonunu da belirlemekte, bu da belirtilen bileşiklein tepe boşluğuna salınmasını etkilemektedir. Fiziko-kimyasal mekanizmaların diğer bir örneği, tuzun uçucu maddelerin açığa çıkmasına neden olduğu bir işlemdir (Saint-Eve ve ark. 2009; Ventanas ve ark. 2010a,b).

Gıda matriks yapısının modifikasyonu, aynı zamanda ağızda gıda parçalanmasıyla ilgili fizyolojik mekanizmalarda değişikliği de tetikleyebilmektedir. Tükürük, sıcaklık, çiğneme kuvveti ve yutma gibi bireysel ağız fizyoloji, matriks yapısına göre de değişebilmektedir (Buettner ve Beauchamp, 2010). Aroma ve tat ayrı fizyolojik yollarla algılanmasına rağmen, birçok araştırmacı, bir tat yoğunluğunun neden aroma algısı ile değiştirilebileceğini açıklamak için psikolojik mekanizmaların da dikkate alınması gerektiğini bildirmiştir (Roudnitzky ve ark. 2011Chen 2014). "Gıda ürününde iki uyaranın bir kombinasyonda ne kadar uygun olduğu" olarak tanımlanan uyum, tat ve aroma arasında dikkate alınması gereken önemli bir kriter olarak ilk kez Schifferstein ve Verlegh (1996) tarafindan açıklanmıştır. Flavor ve aroma uyaranları etkileşimde olduğunda, meyvenin tatlılık veya ekşilik ile etkileşiminin doğru orantılı olduğu belirtilmiştir (sakkaroz seviyesi arttıkça badem aromasının algılanan yoğunluğu artmaktadır) (Tournier ve ark.2009).

Bugüne kadar, tat-aroma etkileşimleri çoğunlukla sıvı veya yarı katı model matrikslerde analiz edilmiş olup, hassas miktarda uçucu ve tat bileşikleri içeren kontrollü koşullar altında formüle edilmiştir.

38 | P a g e

www.iiste.org 
Model matrikslerin yanı sıra gerçek gıda ürünlerinde duyusal etkileşimler yapılan çalışmalarla ele alınmaktadır. Bu, karmaşık uyaranlar söz konusu olduğunda etkileşimlerin çalışmasını karakterize etmenin çok zor olduğunu da belirtilmiştir (Poinot ve ark. 2011; Syarifuddin ve ark. 2016).

Bazı araştırmacılar, aroma-tekstür etkileşiminin bilişsel bir mekanizmaya bağlı olabileceğini ve panelistlerin, ürünün aroması değiştirildiğinde farklı çiğneme davranışını benimseyebileceğini öne sürmektedirler (Saint Eve ve ark. 2004). Bu hipotez, tekstür, tat ve koku veri girişlerinin aynı (olfactory) kortikal alanda birleşmesiyle olduğunu öne sürmektedir (Rolls, 2005). Aroma ile ilgili olarak Lethuaut ve ark. (2004) meyveli karışım konsantrasyonlarının (4.5, 18 ve $72 \mathrm{mg}$. $\mathrm{Kg}^{-1}$ ) muhallebi tatlılarının reolojik özelliklerini (penetrometri) etkilemediğini doğrulamıştır. Bu durumda aroma yoğunluğunun, esneklik ve hassaslık gibi algılanan tekstür özelliklerini etkilediği, ancak s1kılık, kırılganlık ve pürüzsüzlük özelliklerinin değerlendirilmesi üzerinde hiçbir etkisi olmadığ 1 belirlenmiştir. Flavor- tekstür etkileşimleri ile ilgili bir çalışmada, tüketiciler, nose klip takarak ve takmadan iki viskozite seviyesindeki (viskoziteyi sabit tutmak için sakkarozun yarısı laktoz ile değiştirilmiştir) muhallebi tatlılarında ne tatlılık yoğunluğunun ne de aroma algısının tüketicinin ürünün sıkılık/yoğunluk algısı üzerinde herhangi bir etkisi olmadığını belirlemiştir (Tournier, 2006). Tat-aroma etkileşimleri son yıllarda, özellikle psikologlar tarafindan da büyük ilgi görmektedir (Prescott, 2004). Bu çalışmalar genellikle katılımcılara tat ve/veya koku alma bileşiklerinden oluşan bir uyaranın sunulması ve sadece bir uyarandan oluşan örnekler için elde edilen puanların her iki uyarandan oluşan çözelti puanları ile karşılaştırılmasını içermektedir. Birçok çalışma, koku alma uyarısının tat algısı üzerindeki etkisinin olup olmadığını araştırmıştır. Koku uyaranlarının tat algısı üzerindeki etkisi tat arttırıcı ve tat bastırma özelliği açısından yorumlanmaktadır (Harrison, 2000).

Çalışmaların pek çoğu aynı zamanda tatlılık algısına da odaklanmaktadır. Sonuçlar, aromanın tat algısı üzerindeki etkisinin aromanın özelliğine bağlı olduğunu göstermiştir. Çilek, karamel, ve vanilya gibi bazı aromalar algılanan tatlılığ 1 arttırırken, diğerlerinin hiçbir etkisinin olmadığ 1 (kış yeşili, okaliptol, jambon) veya tatlılık algısını (çikolata, damascone yağı ve angelica yağı) azalttığı saptanmıştır (Valentin ve ark. 2006). Tat ve aroma arasındaki etkileşimler, her iki uyaranın bireysel gida deneyimine bağlı olan merkezi entegrasyonuna bağlı bulunmaktadır. Bu nedenle, yaşamları boyunca çilek ile tatlandırılmış tatlı yoğurtları tadan tüketiciler, çilek aromasını tatlı tada bağlayacaktır. Bu alışkanlığın sonucu, farklı ortamlarda yaşayan kişilerin, tat ve aroma arasındaki etkileşimleri değiştirebilecek farklı gıda deneyimlerine sahip olduğu söylenebilir (Tournier ve ark. 2007).

King ve ark. (2007) farklı brix ve asitliğe sahip içeceklerin duyusal profillerinin belirlenmesinde çeşitli tanımlayıcılar için retronazal koku yoğunluklarında farklılıkları gözlemlemiş ve panelin ticari örneklerin profillendirilmesindeki önceki deneyimleri nedeniyle bu etkileşimleri bilimsel psikolojik deneyim ve tecrübelerine bağlamıştır. Örneğin, brix'i 8'den 12'ye çıkarmak veya asitliği 0.3'den 0.2 'ye düşürmek meyveli içeceklerin puanlarını önemli ölçüde arttırmıştır. Diğer taraftan, flavorın, muz aroması veya yeşil elma aroması gibi ortonazal bir "tatlı” kokusu olduğu zaman tatda, tatlılık artışı oluşturduğuna dair hiçbir kanıt bulunamamıştır. Sauvageot ve ark. (2000) tat-aroma etkileşimlerinin kültüre bağlı olduğunu da gözlemlemişlerdir. Tatlı tat ve çilek aroması arasındaki etkileşimin, Amerikan halkı için Fransızlara göre daha güçlü olduğu belirtilmiştir. Bu hipotezi test etmek için Fransız ve Amerikalı katılımcılardan “çilek" kelimesini okuduklarında aklına gelen tüm kelimeleri alıntılamaları istenmiştir. Sonuçlar, Fransızların sadece \%9'unun, Amerikalı kişilerin \%24'üne kıyasla kendiliğinden "çilek" ve "tatlı" ilişkilendirdiğini göstermiştir. Nörofizyolojik çalışmalar aynı kortikal alandaki tat ve koku girişlerinin bu yöntemler arasında bilişsel etkileşimlerin desteklenebileceğinin hatırlanması gerektiğini belirtmektedirler. Rolls (2005) orbitofrontal korteksteki 112 nörondan \%68'inin imimodal nöronlar olduğunu (\%34'ünün sadece tat uyaranlara yanıt verdiğini ve \%13'ünün sadece koku uyaranlarına yanıt verdiğini) ve \%32'sinin ise multimodal olduğunu (\%13'ün koku alma ve tat alma uyaranları) bildirmişlerdir. $\mathrm{Bu}$ farklı nöron türleri genellikle birbirine yakındır ve tek modlu nöronlardan oluşabilmektedir. Ayrıca, orbitofrontal kortekste koku alma nöronlarının yanıtı, kokunun ilişkili olduğu tat ile de değiştirilebilmektedir (Rolls, 2002).

\section{Tekstür - Aroma Etkileşimleri}

Tekstür-aroma etkileşimleri, çoğunlukla, yarı katı veya jel formuna sahip olan hafif karmaşık matrikslerde incelenmiştir. Aromaların tekstür algısı üzerindeki etkisi ile ilgili olarak, aromaların bazı çalışmalarda tekstür algısını değiştirdiği belirtilmiştir. Bult ve ark. (2007) bir 'krema' aromasının

39 | P a g e

www.iiste.org 
varlığının, incelenen ürünlerin algılanan sıkılığını ve kremliliğini arttıracağını ortaya koymaktadır. Saint-Eve ve ark. (2004) ve (2009) yağlı aromaya sahip stirred tipi yoğurtların ve peynirlerin, bu aromalara sahip olmayanlardan daha s1kı yapıları olduğunu belirmektedirler. Tekstürün aroma algısı üzerindeki etkisiyle ilgili olarak, sıvı sistemlerin viskozitesinin veya jel benzeri sistemlerin sertliğinin arttırılmasının aromalarının yoğunluğunu azaltma eğilimi gösterdiği belirtilmiştir (Hollowoodve ark. 2002; Weel ve ark. 2002; Juteau ve ark. 2004; Lethuaut ve ark. 2004; Lethuaut ve ark. 2005; Mestres ve ark. 2005; Boland ve ark. 2006; Ferry ve ark. 2006; Bult ve ark. 2007; Gierczynski ve ark. 2008; SaintEve ve ark. 2011).

Fiziko-kimyasal mekanizmalarla ilgili olarak, bazı stabilize edici hidrokolloidlerin ve tekstür geliştirici bileşenlerin, gıda matriksinde uçucu bileşiklerin doğrudan tutulmalarına yol açarak etkileşime girebileceği kanısı vurgulanmıştır. $\mathrm{Bu}$, özellikle süt proteinleri, yağ, jelatin gibi çeşitli proteinler ve pektin, karboksimetilselüloz gibi bazı hidrokolloidler için geçerli olmaktadır (Arvisenet ve ark. 2002; Boland ve ark. 2006; González-Tomás ve ark. 2007; Saint-Eve ve ark. 2009; Zafeiropoulou ve ark. 2012). Nişastanın ayrıca bazı uçucu maddelerle doğrudan etkileşime girdiği ve 'salting out (yüksek yoğunluktaki tuz çözeltilerinde proteinlerin çökmesi)' etkisi ile aroma bileşiklerinin tutulmalarını veya salınımlarını tetiklediği belirtilmiştir (González-Tomás ve ark. 2007; Keršiene ark. 2008; Arancibia ve ark. 2011). Bu fiziko-kimyasal etkileşimler matrikse, uçucu bileşiğe ve yapılandırıcı maddeye bağlı olarak şekillenmektedir. Örneğin bazı çalışmalarda, aroma ve yapı bileşikleri arasında hiçbir fizikokimyasal etkileşim de görülmemiştir (peynir altı suyu proteini, jelatin, nişasta, pektin, karragenan, hidroksipropilmetil selüloz) (Hollowood ve ark. 2002; Weel ve ark. 2002; Lethuaut ve ark. 2004; Mei ve ark. 2004; Lethuaut ve ark. 2005; González-Tomás ve ark. 2007; Déléris ve ark. 2011).

Bununla birlikte, yağsız matrikslerde elde edilen sonuçlar, kullanılan kıvam arttırıcı ve stablize edici maddenin özelliklerine büyük ölçüde bağlıdır (Arancibiave ark. 2015). Aroma bileşiklerinin hidrofobik-hidrofilik karakterleri birbirinden farklı olmakla birlikte, hidrofilik aroma bileşiklerinin salınımı yağ bileşeninden bağımsız iken, hidrofobik aroma bileşiklerinin salınımı gıda içerisindeki yağ miktarı arttıkça azalmaktadır. Pek çok aroma bileşiği de hidrofobik özelliğinden dolayı yağ içinde çözünmektedir (Chua ve ark. 2017). Lubbers ve ark. (2004), pektin, nişasta ve keçiboynuzu zamk1 içeren yoğurtlarda çilek aroması oluşturan 15 aroma bileşiğinin salınımını araştırmış ve bu üç koyulaştırıcı, yoğurtların görünür viskozitesini ve kıvamını arttırmıştır. Bununla birlikte, sadece nişasta ve keçiboynuzu zamkının aroma salınımı üzerinde önemli, ancak zıt etkileri olduğunu; keçi boynuzu zamkının, daha yüksek bir aroma bileşiği salınımını indüklerken, nişastanın ise azalttığı saptanmıştır. Gıdanın fiziksel matriksinin değiştirilmesi, bireysel fizyolojik ağız davranışı (örneğin tükürük, boğaz kaplama) ve çiğnemenin gücünü, zamanını ve hızını da etkileyebilmektedir. Bu hem mekanik hem de biyokimyasal bozulmalarla bağlantılı çeşitli çapraz-model etkileşimlerine yol açabilmekektedir. Aslında, panelin profiline özgü mekanik çiğneme davranışları da, aroma salınımı ve algısının kinetiklerini etkileyebilmektedir (Mestres ve ark. 2005, 2006; Déléris ve ark. 2011; Mosca ve Chen, 2017).

Gierczynski ve ark. (2008) belirtilen davranışın (çiğneme kuvveti, sıklığı ve süresi, ayrıca velum dil bariyerinin açılması ve kapanması) matriksin yapısına bağlı olduğunu belirtmektedirler. $\mathrm{Bu}$ araştırmacılar, granüler olarak algılanan ve parçalanması heterojen olan daha sıkı bir jelin, tekstür geliştrici bileşen tarafından daha yoğun algılandığını, ve daha kolay tahrip edilmiş olandan daha fazla dikkat gerektirdiği hipotezini formüle etmişlerdir. Sonuç olarak, daha sıkı bir jel için, ağızda fiziksel olarak parçalamada dikkat artarak, tat ve aroma gibi diğer algılara daha az dikkat çekilmektedir ve bu da aromanın daha az yoğun algılanmasına sebep olmaktadır. Hansson ve ark. (2003) pektin içeren gıdalar incelendiğinde, ağızda tutuldukları zamana kıyasla burundaki aroma konsantrasyonlarının yaklaşık iki kat daha yüksek olduğunu belirtmişlerdir. $\mathrm{Bu}$, ağıdaki parçalanmaya göre uçucu maddelerin, gıda matriksi içindeki değişkenliği ile açıklanabilmektedir (Hansson ve ark. 2003; Mestres ve ark. 2005, 2006; Boland ve ark. 2006; Gierczynski ve ark. 2008; Kühn ve ark. 2009; Déléris ve ark. 2011).

Tekstür geliștirici maddeler ve tükürük bileșenleri arasındaki biyokimyasal etkileșimler de aroma algısını etkileyebilmektedir. Ferry ve ark. (2006) nişasta jellerinin tükürük ile etkili bir şekilde karıştığını ortaya koymuşlardır. Bunun, polisakkaritlerin oluşturduğu farklı ağız hissinden ve artan flavor algısından kaynaklanabileceği ortaya konulmuştur. Ayrıca bu sonucun, tükürükteki bir başka önemli faktör olarak, nişastayı parçalayabilen ve matrikslerin viskozitesini birkaç saniye içinde

40 I P a g e

www.iiste.org 
azaltabilen alfa-amilaz enziminin varlığından kaynaklandığını belirtmişlerdir (Ferry ve ark. 2004). Beyine ulaşan viskozite sinyalinin tat ve aroma sinyallerinin işlenmesini modüle etmesi durumunda, matrikslerin viskozitesinin azalmasının flavor algısının artmasına katkıda bulunması beklenmektedir. Ayrıca, tükürük spesifik gıda bileşiminden doğrudan etkilenmektedir, bu da tekstür ve aroma algısı üzerinde geri birleştirme etkisi ile sonuçlanmaktadır (Mestres ve ark. 2006; Mosca ve Chen, 2017). Sonuç olarak, aroma algısının da değiştirilip değiştirilmeyeceği tahmin edilebilir bir özelliktir.

Roudnitzky ve ark. (2011), tekstür-aroma etkileşimleriyle uğraşırken psikolojik mekanizmaların da dikkate alınması gerektiğini bir kez daha vurgulamaktadır. Aynı zamanda psikolojik ve fizyolojik mekanizmalar da bu anlamda örtüşebilmektedir. Bugüne kadar geliştirilen duyusal ve enstrümantal yöntemler çoğunlukla model veya yeniden oluşturulmuş matrikslerdeki etkileşimlerin analiz edilmesini sağlamaktadır. Genel olarak, bunlar tanımlı miktarlarda tat veya yapılandırıcı ve standart uçucu bileşikler içermektedir. Bu tür matrikslerde, kullanılan yöntemler hem etkileşimlerin oluşumunu hem de kaynaklandıkları fiziko-kimyasal, fizyolojik veya psikolojik sebepleri belirleyebilmiştir. Nişasta ve HPMC (hidroksipropil metil selüloz) model sistemleri arasındaki ağız içi davranıştaki farklılıkları, nişasta örneklerinin tükürük ile karışma kapasitesi (Ferry ve ark. 2006) ve bunun tükürük ile enzimatik parçalanması (de Wijk ve ark. 2004) ile açıklanabilmektedir. Tükürük bileşimindeki değişim sadece muhallebili tatlılardaki kremalı ağız hissi gibi tekstür algısını etkilemekle kalmaz, aynı zamanda muhallebi tatlısında vanilya aroması ve mayonezde ki ekşi aroma gibi aroma ve tat algısını da etkilemektedir (Engelen ve ark. 2007).

Ağızda fiziksel parçalanma sırasında gıdanın yapısal değişimi, ağızdaki tükürükten de etkilenmektedir. Yiyecekler tükürük ile ıslatılır ve ağız içine alındıktan sonra tükürük ile kaplanmaktadır (Mosca ve Chen, 2017). Çiğneme yoluyla ağızda parçalama sırasında, gıda partikülleri ya tükürük içinde çözünür veya tükürük ile ıslatılmaktadır. Bu işlem sırasında tükürük, tat ve aroma bileşiklerinin difüzyonunu kolaylaştırmakta ve tat ve aroma salınımı için etkili bir ortam görevi görmektedir. Eşzamanlı olarak, dilin hareketleri ile tükürük, yutma için uygun bir bolus oluşturmak için gıda partiküllerinin kümelenmesini ve toplanmasını kolaylaştırmaktadır. Ağızda daha az tükürük varsa veya gıda ürünleri yapı olarak kuru ve/veya gözenekli ise, daha uzun ağızda işleme süresine (daha fazla tükürük katkısı ile) genellikle ihtiyaç duyulmaktadır. (Mioche ve ark. 2003; Tarrega ve ark. 2011). Gıda matriksinin parçalanma şekline bağlı olarak, çiğnemenin rolü, bir yiyeceği yutmaya hazır bir lokmaya dönüştürmekte ve gıda tekstürü değiştiğinde, tüketici çiğneme süreçlerini adapte etmekte, bu da flavor bileşiklerinin salımını etkileyebilmektedir (Blissett ve ark. 2006). Boland ve ark. (2006) jel sıkılığının çiğneme davranışı ve in vivo aroma salınımı üzerindeki etkisini incelemişlerdir. Yutmadan önceki çiğneme süresinin sıkı jeller için yumuşak jellere kıyasla daha yüksek olduğu ve aroma salım hızının ise daha düşük olduğu tespit edilmiştir. Jel olmayan sistemler için çiğneme gerekli değildir ve bu da aroma algısını değiştirmektedir. Ağız hareketlerinin de yarı katı model sistemler için tekstüre bağlı olduğu ve salınımı etkilediği bulunmuştur (de Wijk ve ark. 2006).

Gıdanın makro yapısı veya ağızdaki durumu ile ilgili çeşitli fiziko-kimyasal mekanizmalar, tat ve aroma bileşikleri salımı üzerinde etkili olabilmektedir ve reseptörlere gelen miktar değiştirilerek de tat ve aroma algısını değiştirebilir. Tekstür-flavor etkileşimlerinde yer alan fiziko-kimyasal mekanizmaları kavramada daha ileriye gitmek için, flavor bileşiklerini kendi reseptörlerine yakın bir şekilde ölçmeyi ve her flavor bileşiği için salınım parametreleri üzerinde elde edilen verileri flavor algısıyla ilgili verilerle ilişkilendirmeyi amaçlamak gerekmektedir. Chabanet ve ark. (2006) tavuk sosis bileşiminin (protein içeriğine rapor edilen yağ, tuz ve kuru ekstrakt) ağızda tuz salınımı ve tuzluluk algısı üzerindeki etkisini incelemiştir. Dört katılımcıdan bir parça sosis çiğnemesi, tükürük örneği tükürmesi ve farklı dönemlerde tuzluluğu değerlendirmesi istenmiş sonuç olarak, tuzluluk algısı, sosis bileşimine oldukça bağımlı bulunmuştur. Tat algısı ile ilgili olarak tat bileşikleri salımını ölçmek için daha fazla gelişmelere ihtiyaç olduğu savunulmuştur. Chanco peynirini inceleyen Leiva ve Figueroa (2010), kimyasal özelliklerin (nem, pH, tuz, toplam kuru madde) pıhtı matriksini etkilediğini ve bazı duyusal özelliklerin (iç yapışkanlık, sertlik, bozulabilirlik) tüketici tarafından nasıl duyumsanacağını belirleyen makro yapının bir parçası olduğunu belirtmektedirler. Lawlor ve ark. (2001) iç yapışkanlığın ve sertliğin peynirin $\mathrm{pH}$ değeri ve kimyasal bileşimiyle yakından ilişkili olduğunu belirtmektedir. Pereira ve ark. (2006)'ne göre duyusal sertlik ve dış yapışkanlık, kimyasal özellikler ile yüksek oranda ilişkilidir.

Aroma algısı ile ilgili olarak, çeşitli çalışmalar tekstür-aroma etkileşimlerini aroma bileşiklerinin in

41 | P a g e

www.iiste.org 
vivo salımıyla ilişkilendirmeye çalı̧̧ıştır. Aroma ile ilişkili etkileşimlerin kökenini belirlemek için enstrümantal yöntemler uygulanmıştır. Bununla birlikte, genel olarak, kullanılan yöntemler matriks tadının fiziko-kimyasal ölçümleri (örneğin, refraktometri ile sükroz konsantrasyonu, Klorür Quantab Strip ile tuz, Fourier Dönüşümlü Kızılötesi Spektrometresi ile protein çökeltme) ve/veya yapı (örneğin, floresan mikroskobu, sıkıştırma testleri, viskozite ölçümü) ile birleştirilmiştir. Bu kullanılan yöntemlerin yanı sıra fizyolojik metodolojiler de ayrıca aroma ölçümü ile birlikte kullanılmıştır. Ağız hareketleri, çiğneme, yutma ve tükürme, zamana bağlı video floroskopi kayitları (Mestres ve ark. 2006) ve gerçek zamanlı manyetik rezonans görüntüleme (MRI) (Buettnerve ark. 2002) yöntemleri ile incelenmiştir. Daha sonra yapılan çalışmalarda ise, algısal etkileşimlerin, nöro-zamansal yönlerini araştırmak için elektrofizyolojik yaklaşımlar kullanılmıştır (Roudnitzkyve ark. 2011).

Aroma ile ilişkili çalışmalar, esas olarak hem enstrümantal yöntemler (Headspace Gas Kromotografi Mass Spectrometry, HS-GC/MS veya MS-burun) hem de duyusal analizler (tanımlayıcı analiz veya TI) kullanılarak uyarlanmıştır (Weel ve ark. 2002; Lethuaut ve ark. 2005; Boland ve ark. 2006; Déléris ve ark. 2011; Zafeiropoulou ve ark. 2012) ve tekstür-aroma etkileşimleri çeşitli gıda matrikslerinde vurgulanmıştır (Poinot ve ark. 2013).

Mestres ve ark. (2005) protein jelleri üzerinde bir çalışma gerçekleștirmiş ve duyusal analizle birlikte aroma bileşiklerinin salınımını incelemek için Proton-Transfer-Reaksiyon Kütle Spektrometrisini kullanmıştır. Aroma salımının jellerin sertliğine göre değişmediğini kanıtlamışlardır ve fiziko-kimyasal salınım hızı, örnekler arasında farklııı göstermiş ve daha sıkı olan jel de salınım gecikmesi olduğu tespit edilmiştir. Araştırmacılar tarafından, çiğneme sırasında daha yumuşak jelin daha hızlı parçalanmasının ve daha yüksek yüzey oluşumunun, flavor bileşiklerinin daha hızlı salımına sebep olduğu belirtilmiştir.

Saint-Eve ve ark. (2006) protein içeriğinin çilek aromalı yoğurtlarda aroma salımı üzerindeki etkisini incelemek amacıyla, kazeinat ile zenginleştirilmiş yoğurtların daha yüksek viskoziteye ve heterojen bir ağa sahip olduğunu ve bunun da aroma bileşiği transferi için daha etkili bir bariyer olabileceğini, böylece statik koşullarda ölçülen aroma bileşiklerinin daha düşük salınım gösterebileceğini açıklamışlardır. Gıda sistemlerinde, protein ve polisakkarit bileșenleri birbiri ile etkileşime girmekte ve bu makro moleküllerin elektrostatik etkileşimler, hidrojen bağları ve Van der Waals kuvvetleri gibi kovalent olmayan etkileşimler ile kurdukları ağlar, aroma salınımında karmaşık bir yapı ortaya çıkarmaktadır (Lubbers ve ark. 2004).

\section{Tüketici Tercihleri}

Genel olarak gıdaların son ürünündeki tekstür algısı insan duyusal değerlendirmesine dayandırılmaktadır. Gıda ürünlerinin kalite kontrolü ve işlenmesi tüketicinin tepkisi göz ardı edilmeden ve onayı tahmin edilerek yapılmaktadır ve yeni ürünlerin oluşturulması da duyusal ve enstrümental testler arasında bir korelasyon kurmayı hedeflemektedir (Paulaana ve Conti-Silva, 2014; Ozcan ve Baysal, 2018). Bu çalışmalar ayrıca, gıdaların besinsel, ekonomik veya ekolojik durumlarının hesaba katılarak formüle edilmesine de katkıda bulunmaktadır (Sethupathy ve ark. 2020). Ayrıca, gıdaların görünüş, tekstür ve kemosensör özelliklerden oluşan duyusal kalite algısı, tüketici tarafindan ürünün kabulünün temel taşı olmakla birlikte, bir ürünün tüketim alışkanlıklarını kazanabilmek için de beklentileri açıklayabilmektedir (Şekil 6) (Tuorila ve Hartmann, 2020). 


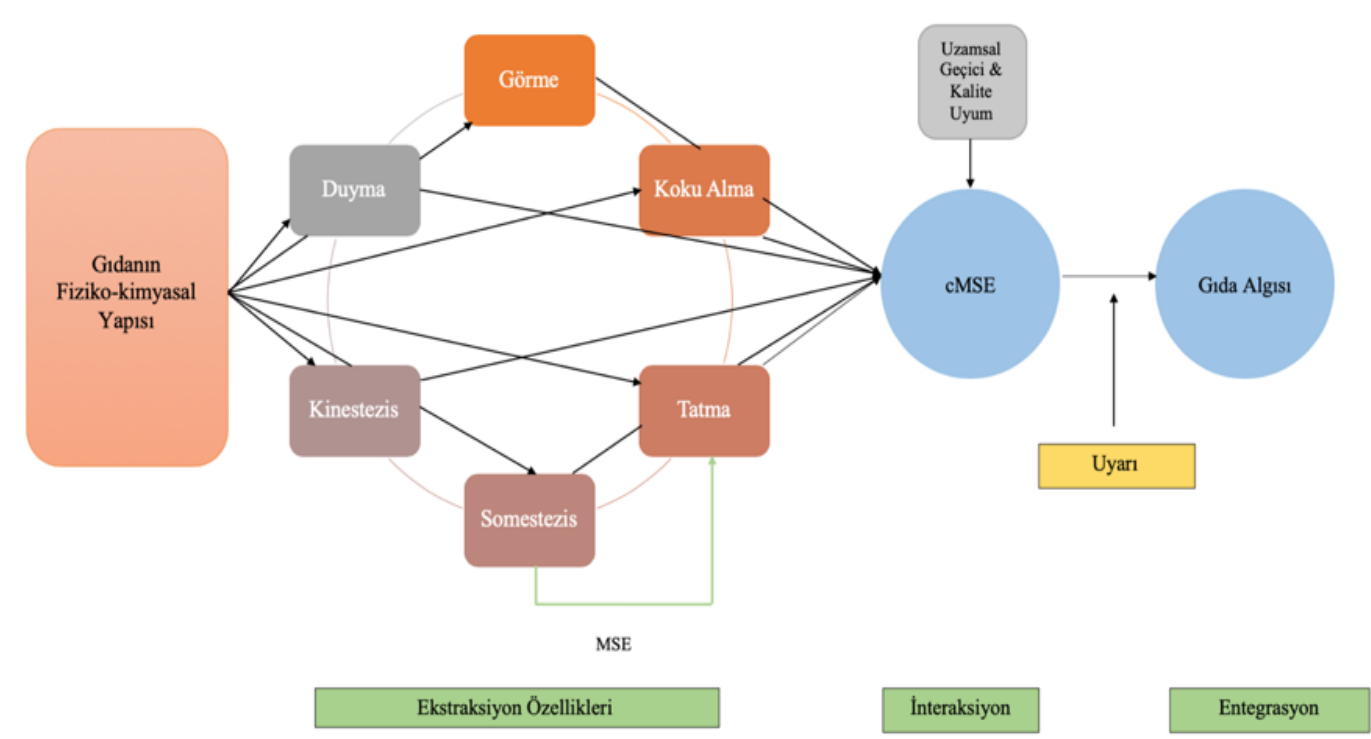

Şekil 6. Sinir sistemiyle gıda algısının oluşturulması (Verhagen ve Engelen, 2006)

Duyusal bir perspektiften bakıldığında, araştırmacılar kalıtsal bir özellik olan tat fizyolojisinin, tüketici zevklerini, yiyecek ve içecek tercihlerini önemli ölçüde etkilediğini savunmaktadırlar (Hayes ve Keast, 2011). Son yıllarda, gıda ve sağlık arasındaki bilincin gelişmesi ile, sağlığı geliştirici özelliklere sahip ürünler olan fonksiyonel gıdalar için yeni bir pazar oluşmuştur (Santeramo ve ark. 2018). Bu tür gıdalar şeker, tuz veya yağı azaltılmış, protein içeriği arttırılmış, sağlığı geliştiren bileşenler eklenmiş veya zararlı bileşenleri çıkarılmış nutrasötik gıdalar olabilmektedir. Son trendler ise organik tarım (Kushwah ve ark. 2019), 3D baskı teknolojisi (Lupton ve Turner, 2018) ve genetik modifikasyon (Royzman ve ark. 2017) gibi yeni veya var olan ürünlerin geliştirilmesi konusunda yoğunlaşmaktadır. Organik gıda ürünleri geleneksel gıda tüketiminde bir tercih haline gelmektedir. Araştırmalar, tüketicilerin temel olarak organik ürünleri daha güvenli, daha sağlıklı, hayvan refahı ve çevre bilinci için daha iyi olduğuna inandıkları için tükettiklerini göstermektedir (Massey ve ark. 2018). Tüketicilerin fonksiyonel gıdaları nasıl ve neden satın aldıklarını anlamak, fonksiyonel gıda sektörünün sürdürülebilir gelişimi için büyük önem taşımaktadır. Bu nedenle çok sayıda araştırma, fonksiyonel gıdaları referans alarak tüketici satın alma niyetini, kabulünü ve tüketimini incelemeye ve açiklamaya çalışmıştır (Nystrand ve ark. 2020). Bu tür çalş̧malar, demografik faktörler (örn. yaş ve cinsiyet), psikolojik faktörler (örn. bilgi, algılanan faydalar, sağlık, güvenlik, beslenme ve tutumlarla ilgili endişeler), durumsal faktörler (örn. fiyat ve bulunabilirlik) dahil olmak üzere ilgili etkili faktörleri vurgulamıştır (Pappalardo ve Lusk, 2016; Bimbo ve ark. 2017).

\section{Sonuç}

Gıdaların ağızda işlenmesinde tekstür-flavor-tat algıları tüketicilerin gıda kabulü ve tercihine yol açmaktadır. Bununla birlikte, dünyada çok sayıda benzersiz populasyon bulunmaktadır ve bu toplumların yeme davranışlarını, özellikle çiğneme ve yutma kabiliyetini göz önünde bulundurarak, uygun tekstüre ve tada sahip ürünler tasarlamak ve üretmek son yıllarda da son derece önemli hale gelmektedir. Yemek yerken veya içerken yaşanan tüm duyumların bu deneyim için çok önemli olması veya birçok duyunun algısal düzeyde birbiriyle etkileşime girmesi şaşırtıcı değildir. Kesin olan bir şey vardır oda, tat, tekstür, koku, dokunma, sıcaklık, görme, duyma ve bazen ağrı/tahriş, yiyecek ve içeceklerin kabul edilip edilmeyeceği konusunda büyük bir etkiye sahiptir. Bu derlemede tat, aroma ve tekstür arasındaki etkileşimler ile bu etkileşimlerin fiziko-kimyasal mekanizmalarından bahsedilmiştir. Tat-aroma etkileşim mekanizmaları genel anlamda tanımlanmış olsa bile, tekstürün flavor algısı üzerindeki etkisinin kökenindeki gerçekler oldukça karmaşıktır. Duyusal, fiziko-kimyasal ve psikolojik yaklaşımlarının birleştirilmesi ile bu etkileşimlerin incelenmesi gerektiğini ortaya konulmuştur.

Gıdaların ve duyusal algının temel mekanizmalarını ortaya çıkarmak için daha fazla araştırma yapılması gerekmektedir. Tükürüğün katı, yarı katı ve sıvı gıdalarla olan çapraz etkileşimleri ve karşı1ık 
gelen duyusal ve aromatik algılar da dahil olmak üzere farklı perspektiflerden daha fazla inceleme yapılmalıdır. Seyreltme etkisi, protein ve yağ içeriği, gıda matriksi ile enzimatik reaksiyonlar gibi tükürüğün fonksiyonelliğini etkileyen birçok etkiyi düşünmek gerekmektedir. Dilin gıdaların ağızda fiziksel olarak işlenmesi sırasında, özellikle farklı gıda türlerinde nasıl davrandığının hala kapsamlı bir araştırılmasına ihtiyacı bulunmaktadır. Bu araştırmalar, gıda bilimcileri, oral fizyologlar, nöro-fizik ve klinik doktorların ortak çabalarını gerektirmektedir.

Gıda endüstrisi için, yeni ürün geliştirme en önemli yaklaşımlardan biridir. Yenilikçi ürünlerin geliştirilme sürecinde, kavram geliştirme, prototip oluşturma, patent araştırması, piyasa trendlerinin ve piyasadaki rekabetçi ürünlerin incelenmesi ve ticarileştirmenin yeni bir ürünün başarısı için kritik adımlar olduğu bilinmektedir. Eğitimli panelistler tarafından geliștirilen tanımlayıcı testler ve duyusal sözlükler, basit model sistemler, in vivo ve in vitro testler yeni bir ürün geliştirme sürecinde flavor salınımı ile flavor algısını anlamak için etkili yaklaşımlar olabilir. Bununla birlikte, gıda matriksleri karmaşık çok fazlı sistemlerdir. Farklı fazların stabilizasyonu, gıdanın tekstürünü ve dolayısıyla flavor bileşiklerinin çiğneme sırasında gıdanın farklı fazlarında ve tükürükte difüzyonunu belirleyecektir. Gıdalar üzerine yapılan araştırmalar, çiğneme sırasındaki tekstür matriksindeki değişmeler ve tekstürduyusal korelasyonunun ile dikkate alınmasını gerektirmektedir.

\section{Kaynaklar}

Arancibia, C., Castro, C., Jublot, L., Costell, E. \& Bayarri, S. (2015). Colour, rheology, flavour release and sensory perception of dairy desserts. influence of thickener and fat content. Lebensmittel-Wissenschaft Und-Technologie-Food Science and Technology, 62, 408-416.

Arancibia, C., Jublot, L., Costell, E. \& Bayarri, S. (2011). Flavor release and sensory characteristics of o/w emulsions. influence of composition, microstructure and rheological behavior. Food Research International, 44, 1632-1641.

Arvisenet, G., Le Bail, P., Voilley, A. \& Cayot, N. (2002). Influence of physico- chemical interactions between amylose and aroma compounds on the retention of aroma in food-like matrices. Journal of Agricultural and Food Chemistry, 50, 7088-7093.

Bimbo, F., Bonanno, A., Nocella, G., Viscecchia, R., Nardone, G., De Devitiis, B. \& Carlucci, D. (2017). Consumersacceptance and preferences for nutrition-modified and functional dairy products, a systematic review. Appetite, 113, 141-154.

Blissett, A., Hort, J. \& Taylor, A.J. (2006). influence of chewing and swallowing behavior on volatile release in two confectionery systems. Journal of Texture Studies, 37, 476-496.

Boakes, R. A. \& Hemberger, H. (2012). Odour-modulation of taste ratings by chefs. Food Quality and Preference, 25, 81-86.

Boland, A.B., Delahunty, C.M. \& Van Ruth, S.M. (2006). influence of the texture of gelatin gels and pectin gels on strawberry flavour release and perception. Food Chemistry, 96, 452-460.

Bourne, M. (2002). Food texture and viscosity, concept and measurement; Elsevier, London.

Briand L. \& Salles C. (2016). Taste perception and integration. Flavor from food to behaviors, Wellbeing and Health Woodhead Publishing Series in Food Science, Technology and Nutrition, pp:101-119.

Bridges, J., Smythe, J. \& Reddrick, R. (2017). Impact Of SalivaryEnzyme Activity on the Oral Perception of StarchContainingFoods. JournalTextureStudies, 48, 288-293.

Buettner, A. \& Beauchamp, J. (2010). chemical input-sensory output, diverse modes of physiologyflavour interaction. Food Quality and Preference, 21, 915-924.

44 I P a g e

www.iiste.org 
Buettner, A. \& Schieberle, P. (2000). Influence of mastication on the concentrations of aroma volatiles-some aspects of flavour release and flavour perception. Food Chemistry, 71, 347-354.

Buettner, A., Beer, A., Hannıg, C., Settles, M. \& Schieberle, P. (2002). Physiological and analytical studies on flavor perception dynamics as induced by the eating an swallowing process.Food Quality and Preference, 13, 497-504.

Buettner, A., Beer, A., Hannig, C. \& Settles, M. (2001). Observation of the swallowing process by application of videofluoroscopy and real-time magnetic resonance imaging - consequences for retronasal aroma stimulation. Chemical Senses, 26, 1211-1219.

Bult, J.H.F., De Wijk, R.A. \& Hummel, T. (2007). Investigations on multimodal sensory integration, texture, taste, and ortho- and retronasal olfactory stimuli in concert. Neuroscience Letters, 411, 6-10.

Burseg, K.M.M., Camacho, S., Knoop, J. \& Bult, J.H.F. (2010). Sweet taste intensity is enhanced by temporal fluctuation of aroma and taste, and depends on phase shift. Physiology and Behavior, 101, 726-730.

Burseg, K., Camacho, S. \& Bult, J.H. (2011). Effects of pulsation rate and viscosity on pulsationinduced taste enhancement, new insights into texture-taste interactions. Journal of Agricultural and Food Chemistry, 59, 5548-5553.

Carpenter, G. \& Blissett, A. (2017). Mastication, salivation and their interactions during eating. Time- Dependent Measure Perception in Sensory Evaluation. pp: 25-47.

Carstens, E., Carstens, M.I., O’Mahony, D.J.M., Simons, M., Makoto, C.T. \& Sudo, S. (2002). It hurts so good, oral irritation by spices and carbonated drinks and the underlying neural mechanisms. Food Quality and Preference, 13, 431-443.

Carvalho-Da-Silva, A.M., Van Damme, I., Taylor, W., Hort, J. \& Wolf, B. (2013). Oral processing of two milk chocolate samples. Food Function, 4, 461-469.

Cayot, N., Pretot, F., Doublier, J.L., Meunier, J.M. \& Cuchard, E. (2004). Release of isoamyl acetate from starch pastes of various structures, theromdynamic and kinetic parameters. Journal of Agricultural and Food Chemistry, 52, 5436-5442.

Chabanet, C., Siret, F., Septier, C. \& Salles, C. (2006). Relationships Between Composition, Salt Release and Saltiness in Chicken Sausage. IUFOST, XII World Congress of Food Science and Technology, 17-21 September, Nantes, France, pp: 1567-1568.

Chandrashekar, J., Hoon, M.A., Ryba, N.J.P. \& Zuker, C.S. (2006). The receptors and cells for mammalian flavour. Nature, 444, 288-294.

Chen, J. (2008). Food oral processing- a review. Food Hydrocolloids, 23,1e25.

Chen, J. (2014). Food oral processing, some important underpinning principles of eating and sensory perception.Food Structure, 1, 91-105.

Chen, J. (2015). food oral processing, mechanisms and implications of food oral destruction. Trends Food Science Technology, 45, 222-228.

Chen, J. \& Stokes, J.R. (2012). Rheology and tribology, two distinctive regimes of food texture sensation. Trends Food Science Technology, 25, 4-12. 
Chua, D., Deeth, H.C., Oh, H.E. \& Bansal, N. (2017). Altering the casein to whey protein ratio to enhance structural characteristics and release major yoghurt volatile aroma compounds of non fat stirred yoghurts. Jounal Dairy Science, 74, 63-73.

Cook, D.J., Hollowood, T.A., Linforth, R.S.T. \& Taylor, A.J. (2005). Correlating instrumental measurements of texture and flavour release with human perception. International Journal of Food Science and Technology, 40, 631-641.

De Lavergne, M.D., Van De Velde, F. \& Stieger, M. (2017). Bolus matters, the influence of food oral breakdown on dynamic texture perception. Food Function, 8, 464-480.

De Wijk, R.A., Prinz, J.F., Engelen, L. \& Weenen, H. (2004). The role of a-amylase in oral texture perception.Physiology \& Behavior, 83, 81-91.

De Wijk, R.A., Wulfert, F. \&Prinz, J.F. (2006). Oral processing assessed by m-mode ultrasound imaging varies with food attribute. Physiology \& Behavior, 89, 15-21.

Déléris, I., Saint-Eve, A., Dakowski, F., Sémon, E., Le Quéré, J.L. \& Guillemin, H. (2011). The dynamics of aroma release during consumption of candies of different structures, and relationship with temporal perception. Food Chemistry, 127, 1615-1624.

Dickinson, E. (2018). On the road to understanding and control of creaminess perception in food colloids. Food Hydrocolloids, 77, 372-385.

Dijksterhuis, G.B. \& Piggott, J.R. (2001). Dynamic methods of sensory analysis. Trends in Food Science and Technology, 11, 284-290.

Duprat-De-Paule, S., Guilbot, J., Roso, A., Cambos, S. \& Pierre, A. (2018). Augmented bio-based lipids for cosmetics.OCL. 25, D503.

Engelen, L., \& Van Der Bilt, A. (2008). Oral physiology and texture perception of semisolids. Journal of TextureStudies, 39, 83-113.

Engelen, L., Van Den Keybus, P.A.M., De Wijk, R.A., Veerman, E.C.I., Amerongen, A.V.N., Bosman. F., Prinz, J.F., \&Van Der Bilt, A. (2007). The effect of saliva composition on texture perception of semi-solids. Archives of Oral Biology, 52, 518-525.

Ermakov, S.F. \& Myshkin, N.K. (2018). Liquid-crystal nanomaterials, tribology and applications; Springer, Switzerland, Vol. 267.

Ferry, A.L., Hort, J., Mitchell, J.R., Cook, D.J., Lagarrigue, S. \& Valles-Pamies, B. (2006). Viscosity and flavour perception, why is starch different from hydrocolloids? Food Hydrocolloids, 20, 855-862.

Ferry, A.L., Hort, J., Mitchell, J.R., Lagarrigue, S. \& Valles-Pamies, B. (2004). Effect of amylase activity on starch viscosity and its implications for flavor perception. Journal of Texture Studies, $35,511-524$.

Firestein, S. (2001). How the olfactory system makes sense of scents. Nature, 413, 211-218.

Fiszman, S.; Tarrega, A. (2018). The dynamics of texture perception of hard solid food, a review of the contribution of the temporal dominance of sensations technique. Journal Texture Studies, 49, 202-212. 
Foegeding, E.A. \& Drake, M.A. (2007). Invited review, sensory and mechanical properties of cheese texture. Jounal Dairy Science, 90, 1611-24.

Foegeding, E.A., Daubert, C.R., Drake, M.A., Essick, G., Trulsson, M., Vinyard, C.J.\& Van De Velde, F.A. (2011). Comprehensive approach to understanding textural properties of semi-and soft- solid foods. Journal Texture Studies, 42, 103-129.

Foster, K.D., Grigor, J.M.V., Cheong, J.N., Yoo, M.J.Y., Bronlund, J.E. \& Morgenstern, M.P. (2011). The role of oral processing in dynamic sensory perception. Jounal Food Science,76, R49-61.

Francis, S.T. \& Eldeghaidy, S. (2015). Imaging methodologies and applications for nutrition research, what can functional MRI offer? Proceedings of the Nutrition Society, 74, 89-98.

Funami, T. (2017). In vivo and rheological approaches for characterizing food oral processing and usefulness of polysaccharides as texture modifiers-a review. Food Hydrocolloids, 68, 2-14

García-Estévez, I., Ramos-Pineda, A.M. \& Escribano-Bailón, M.T. (2018). Interactions between wine phenolic compounds and human saliva in astringency perception. Food Function, 9, 12941309.

Gibbins, H.L. \& Carpenter, G.H. (2013). Alternativemechanisms of astringency-what is the role of saliva?JournalTextureStudies, 44, 364-375.

Gierczynski, I., Laboure, H. \& Guichard, E. (2008). In vivo aroma release of milk gels of different hardnesses, inter-individual differences and their consequences on aroma perception. Journal of Agricultural and Food Chemistry, 56, 1697-1703.

Goldstein, E. B. (2009).Encyclopedia of Perception; Sage, Los Angeles,. Vol. 1.

González-Tomás, L., Bayarri, S., Taylor, A.J. \& Costell, E. (2007). Flavour release and perception from model dairy custards. Food Research International, 40, 520-528.

Guichard, E., Galindo-Cuspinera, V. \& Feron, G. (2018). Physiological mechanisms explaining human differences in fat perception and liking in food spreads-a review. Trends Food Science Technology, 74, 46-55.

Hansson, A., Giannouli, P. \& Van Ruth, S. M. (2003). The influence of gel strength on aroma release from pectin gels in a model mouth and in vivo monitored with proton-transfer-reaction mass spectrometry. Journal of Agricultural and Food Chemistry, 51, 4732-4740.

Harrison, M. (2000). Mathematical models of release and transport of flavors from foods in the mouth to the olfactory epithelium. In ACS Symposium. Washington, DC: American Chemical Society; 1999. Series Vol. 763, pp: 179-191.

Hayes, J.E. \& Keast, R.S.J. (2011). Two decades of supertasting, where do we stand? Physiology \& Behavior, 104, 1072-1074.

Heenan, S., Soukoulis, C., Silcock, P., Fabris, A., Aprea, E. \& Cappellin, L. (2012). PTR-TOF-MS Monitoring of in vitro and in vivo flavour release in cereal bars with varying sugar composition. Food Chemistry, 131, 477-484. 
Hewson, L., Hollowood, T., Chandra, S. \& Hort, J. (2008). Taste-aroma interactions in a citrus flavoured model beverage system, similarities and differences between acid and sugar type. Food Quality and Preference, 19, 323-334.

Hollowood, T. A., Linforth, R. S. T. \& Taylor, A. J. (2002). The effect of viscosity on the perception of flavour.Chemical Senses, 27, 583-591.

Hort, J. \& Hollowood, T.A. (2004). Controlled continuous flow delivery system for investigating taste-aroma interactions. Journal of Agricultural and Food Chemistry, 52, 4834-4843.

Juteau, A., Tournier, C. \& Guichard, E. (2004). Influence of type and amount of gelling agent on flavour perception, physicochemical effect or interaction between senses? Flavour and Fragrance Journal, 19, 483-490.

Keršiene, M., Adams, A., Dubra, A., De Kimpe, N. \& Leskauskaite, D. (2008). Interactions between flavour release and rheological properties in model custard desserts, effect of starch concentration and milk fat. Food Chemistry, 108, 1183-1191.

King, B.M., Duineveld, C.A.A., Arents, P., Meyners, M., Schroff, S.I. \& Soekhai, S.T. (2007). Retronasal odor dependence on tastants in profiling studies of beverages. FoodQualityPreference, 18, 286-295.

Kravchuk, O., Torley, P. \& Stokes, J.R. (2012). Food texture is only partly rheology. in food materialscience and engineering., Ed.: Bhandari, B., Roos, Y. H., United Kingdom: Blackwell Publishing,pp: 349-372.

Kremer, S., Mojet, J. \& Kroeze, J.A.H. (2005). Perception of texture and flavor in soups by elderly and young subjects.Journal of Texture Studies, 36, 255-272.

Kremer, S., Mojet, J. \& Kroeze, J.H.A. (2007b). Differences in perception of sweet and savoury waffles between elderly and young subjects. Food Quality and Preference, 18, 106-116.

Kushwah, S., Dhir, A. \& Sagar, M. (2019). Understanding consumer resistance to the consumption of organicfood. a study of ethical consumption, purchasing, and choice behaviour. FoodQualityPreference, 77, 1-14.

Kühn, J., Delahunty, C.M., Considine, T. \& Singh, H. (2009). In-Mouth flavour release from milk proteins.International Dairy Journal, 19, 307-313.

Labbe, D. \& Martin, N. (2009). Impact of novel olfactory stimuli at supra and subthreshold concentrations on the perceived sweetness of sucrose after associative learning. Chemical Senses, 34, 645-651.

Labbe, D., Damevin, L., Vaccher, C., Morgenegg, C. \& Martin, N. (2006). Modulation of perceived taste by olfaction in familiar and unfamiliar beverages.Food Quality and Preference, 17, 582589.

Labbe, D., Rytz, A., Morgenegg, C., Ali, S. \& Martin, N. (2007). Subthreshold olfactory stimulation can enhance sweetness. Chemical Senses, 32, 205-214.

Lawlor, J., Delahunty, C., Wilkinson, M. \& Sheehan. J. (2001). Relationshipsbetween the sensory characteristics, neutral volatile composition and gross composition of ten cheese varieties. le lait, DairyScience andTechnology. 81, 487- 507. 
Lawrence, G., Salles, C., Septier, C., Busch, J. \& Thomas-Danguin, T. (2009). Odour- taste interactions, a way to enhance saltiness in low-salt content solutions.Food Quality and Preference, 20, 241-248.

Leclercq, S. \& Blancher, G. (2012). Multimodal sensory integration during sequential eating linking chewing activity, aroma release, and aroma perception over time. Chemical Senses, 37, $689-700$

Leiva, J. \& Figueroa, H. (2010). Texture of chanco cheese, projection of a sensory map based on multivariate analysis. ciencia e investigación agraria, 37, 85-91.

Leon, M. \& Johnson, B.A. (2003). Olfactorycoding in the mammalian olfactory bulb. Brain ResearchReviews, 42, 23-32.

Lethuaut, L., Brossard, C., Meynier, A., Rousseau, F., Llamas, G. \& Bousseau, B. (2005). Sweetness and aroma perceptions in dairy desserts varying in sucrose and aroma levels and in textural agent.International Dairy Journal, 15, 485-493.

Lethuaut, L., Weel, K.G.C., Boelrijk, A.E.M. \& Brossard, C. (2004). Flavor perception and aroma release from model dairy desserts.Journal of Agricultural and Food Chemistry, 52, 3478-3485.

Lillford, P.J. (2011). The importance of food microstructure in fracture physics and texture perception. Journal Texture Studies, 42, 130-136.

Lindemann, B. (2001). Receptors and transduction in taste. Nature, 413, 219-225.

Liu, D., Deng, Y., Sha, L., Hashem, M.A. \& Gai, S. (2017). Impact of oral processing on texture attributes and taste perception. Journal Food Science Technology, 54, 2585-2593.

Liu, Y. Gao, J.H., Liu, H.L. \& Fox, P.T. (2000). The temporal response of the brain after eating revealed by functional MRI. Nature. 29,405, 1058-62.

Lubbers, S., Decourcelle, N., Vallet, N. \& Guichard, E. (2004). Flavor release and rheology behavior of strawberry fatfree stirred yoghurt during storage. Jounal of Agricultural Food Chemistry, 52, 3077-3082.

Luckett, C.R., Meullenet, J.F. \& Seo, H.S. (2016). Crispness level of potato chips affects temporal dynamics of flavor perception and mastication patterns in adults of different age groups. Food Quality and Preference, 51, 8-19.

Lupton, D. \& Turner, B. (2018). Food of the future? consumer responses to the idea of 3d-printed meat and insect-based foods. Food and Foodways, 26, 269-289.

Marks, L.E., Shepard, T.G., Burger, K. \& Chakwin, E.M. (2012). Flavor-intensity perception, effects of stimulus context. Physiology and Behavior, 105, 443-450.

Massey, M., O'Cass, A. \&Otahal, P. (2018). A meta-analytic study of the factor driving the purchase of organic Food. Appetite, 125, 418-427.

Mei, J.B., Reineccius, G.A., Knighton, W.B. \& Grimsrud, E.P. (2004). Influence of strawberry yogurt composition on aroma release.Journal of Agricultural and Food Chemistry, 52, 62676270 . 
Meilgaard, M.C., Carr, B.T. \& Civille, G.V. (2007). Sensory Evaluation Techniques, $4^{\text {th }}$ Ed. CRC Press, New York.

Mestres, M., Kieffer, R. \& Buettner, A. (2006). Release and perception of ethyl butanoate during and after consumption of whey protein gels, relation between textural and physiological parameters. Journal of Agricultural and Food Chemistry, 54, 1814-1821.

Mestres, M., Moran, N., Jordan, A. \& Buettner, A. (2005). Aroma release and retronasal perception during and after consumption of flavored whey protein gels with different textures. 1. in vivo release analysis.Journal of Agricultural and Food Chemistry, 53, 403-409.

Mioche, L., Boundial, P. \& Peyron, M.A. (2004). Influence of age on mastication, effects on eating behavior. NutritionResearchReviews, 17, 43-54.

Mosca, A.C. \& Chen, J. (2017). Food-saliva interactions, mechanisms and implications. Trends Food Science Technology, 66, 125-134.

Nasri, N., Beno, N., Septier, C., Salles, C. \& Thomas-Danguin, T. (2011). Cross-modal interactions between taste and smell, odour-induced saltiness enhancement depends on salt level. Food Quality and Preference, 22, 678-682.

Negoias, S., Visschers, R., Boelrijk, A.,\& Hummel, T. (2007). New ways to understand aroma perception. FoodChemistry, 108, 1247-1254.

Nystrand, B.T. \& Olsen, S.O. (2020). Consumers' attitudes and intentions toward consuming functional foods in norway. FoodQualityandPreference, 80, 103827.

Oatley, K. (2017). Perceptions and Representations, The Theoretical Bases of Brain Research and Psychology; Routledge, London.

Onozuka, M., Fujita, M., Watanabe, K., Hirano, Y., Niwa, M., Nishiyama, K., Saito, S. 2002. Mapping brain region activity during chewing, a functional magnetic resonance imaging study. journal of dental research, 811, 743-746.

Ozcan, T. \& Baysal, S. (2018). Textural attributes of white cheeses, correlation with instrumental and sensory measurements, international symposium on food rheology and texture, 19-21 October, İstanbul, Turkey, 158-163.

Özdemir, T. \& Özcan, T. (2019). Sütürünlerinin mikroyapısının oluşumunda süt proteinlerinin önemi. Bursa Uludağ Üniversitesi Ziraat Fakültesi Dergisi, 2, 355-374.

Pappalardo, G. \& Lusk, J.L. (2016). The role of beliefs in purchasing process of functional foods. Food Quality and Preference, 53,151-158.

Paulaana, A.M. \& Conti-Silva, C. (2014). Texture profile and correlation between sensory and instrumentalanalyses on extruded snacks. Journal of Food Engineering, 121, 9-14.

Pereira, R., Matia-Moreno, L., Jones, V. \& Singh, H. (2006). Influence of fat on the perceived texture of set acid milk gels, a sensory perspective. Food Hydrocolloids, 20, 305-313.

Peyron, M.A., Santé-Lhoutellier, V., François, O. \& Hennequin, M. 2018. Oral declines and mastication deficiencies cause alteration of food bolus properties. FoodFunction, 9, 1112-1122. 
Poinot, P., Arvisenet, G., Texier, F., Lethuaut, L., Mehinagic, E., Vigneau, E. 2011. Use of sense masking to study sensory modalities singly, interest for the understanding of apple in-mouth perception. Food Quality and Preference, 22, 573-580.

Poinot, P., Arvisenet, G., Ledauphin, J., Gaillard, J.L. \& Prost, J. (2013). How can aroma-related cross-modal interactions be analysed? a review of current methodologies. Food Quality and Preference, 28, 304-316.

Prakash, S., Tan, D.D.Y. \& Chen, J. (2013). Applications of tribology in studying food oral processing and texture perception. Food Research International, 54, 1627-1635.

Prescott, J., Johnstone, V. \& Francis, J. (2004). Odor-taste interactions, effects of attentional strategies during exposure. Chemical Senses, 29, 331-340.

Prinz, J.F., Janssen, A.M. \&De Wijk, R.A. (2007). In vitro simulation of the oral processing of semisolid Foods. Food Hydrocolloids, 21, 397-401.

Quintero, A., Ichesco, E., Myers, C., Schutt, R. \& Gerstner, G. E. (2013). Brain activity and human unilateral chewing, an FMRI study. Journal of Dental Research, 92, 136-142.

Repoux, M., Labouré, H., Courcoux, P., Andriot, I., Sémon, É., Yven, C., Feron, G. \& Guichard, E.,(2012). Combined effect of cheese characteristics and food oral processing on in vivo aroma release. Flavour and Fragrance Journal, 27, 414-423.

Rolls, E.T. (2002). The Cortical Representation of Taste and Smell. Ed.: Rouby C, Schaal B, Holley A, Dubois D, Gervais R.Olfaction, taste and cognition, The Press Syndicate of the University of Cambridge, Cambridge, UK, pp: 367-387.

Rolls, E.T. (2005). Taste, olfactory, and food texture processing in the brain, and the control of food intake. Physiology \& Behavior, 85, 45-56.

Ross, C.F. (2009). TheSensory Evaluation of DairyProducts:Physiology of SensoryPerception. $E d$. :Clark, S., Costello, M., Drake, M., Bodyfelt, F., Chapter 3, pp: 17-42.

Roudnitzky, N., Bult, J.H.F., De Wijk, R.A., Reden, J., Schuster, B. \& Hummel, T. (2011). Investigation of interactions between texture and ortho- and retronasal olfactory stimuli using psychophysical and electrophysiological approaches.Behavioural Brain Research, 216, 109-115.

Royzman, E., Cusimano, C. \& Leeman, R.F. (2017). Whatlies beneath? fear vs. disgust as affective predictors of absolutist opposition to genetically modified food and other new technologies. JudgmentandDecisionMaking, 12, 466.

Saint-Eve, A., Déléris, I., Panouillé, M., Dakowski, F., Cordelle, S. \& Schlich, P. (2011). How texture influences aroma and taste perception over time in candies. Chemosensory Perception, 4 , $32-41$.

Saint-Eve, A., Lauverjat, C., Magnan, C., Déléris, I. \& Souchon, I. (2009). Reducing salt and fat content, impact of composition, texture and cognitive interactions on the perception of flavoured model cheeses.Food Chemistry, 116, 167-175.

Saint-Eve, A., Martin, N., Guillemin, H., Semon, E., Guichard, E. \& Souchon, I. (2006). Flavored yogurt complex viscosity influences real-time aroma release in the mouth and sensory properties. Journal of Agricultural and Food Chemistry, 54, 7794 -7803. 
Saint-Eve, A., Paci Kora, E. \& Martin, N. (2004). Impact of the olfactory quality and chemical complexity of the flavouring agent on the texture of low fat stirred yogurts assessed by three different sensory methodologies.Food Quality and Preference, 15, 655-668.

Salles, C., Chagnon, M.C., Feron, G., Guichard, E., Laboure, H., Morzel, M., Semon, E., Tarrega, A. \& Yven, C. (2011). In-mouth mechanisms leading to flavor release and perception.Critical Reviews Food Science and Nutrition, 51, 67-90.

Santeramo, F.G., Carlucci, D., De Devitiis, B., Seccia, A., Stasi, A., Viscecchia, R. \& Nardone, G. (2018). Emergingtrends in european food, diets and food industry. FoodResearch International, $104,39-47$.

Sarkar, A. \& Singh, H. (2012). Fundamentals of eating and sensory perception: Oral behaviour of food emulsions. in food oral processing. Ed.: Chen, J., Engelen, L., UK, Wiley-Blackwell, pp: $111-137$

Sauvageot, F., Nguyen, H.D. \& Valentin, D. (2000). Les mots évoquentils des saveurs? une comparaison entre étudiants de france, du vietnam et des USA. Sciences Des Aliments, 20, 491522.

Schifferstein, H.N.J. \& Verlegh, P.W.J. (1996). The role of congruency and pleasantness in odorinduced taste enhancement. Acta Psychologica, 94, 87-105.

Schipper, R.G., Silletti, E. \& Vingerhoeds, M.H. (2007). Saliva as researchmaterial, biochemical, physicochemical and practical aspects. Archives of Oral Biology, 52, 1114-1135.

Sethupathy, P., Moses J.A. \& Anandharamakrishnan, C. (2020). food oral processing and tribology, instrumental approaches and emerging applications.Food Reviews International, 1525-6103.

Shafi, W.K., Raina, A., Haq, M.I.U. \& Khajuria, A. (2018). Applications of industrial tribology. International Research Journal of Engineering and Technology. 5, 1285-1289.

Sicard, G. (2002). Odorcoding at the periphery of the olfactory system. Ed.: in Rouby, C., Schaal, B., Dubois, D., Gervais, R., Holley, A., Olfaction, Taste, andCognition, Cambridge, United Kingdom: Cambridge UniversityPress, pp: 293-308.

Siefarth, C., Tyapkova, O., Beauchamp, J., Schweiggert, U., Buettner, A. \& Bader, S. (2011). Mixture design approach as a tool to study in vitro flavor release and viscosity interactions in sugar-free polyol and bulking agent solutions. Food Research International, 44, 3202-3211.

Simon, S.A., De Araujo I.E., Gutierrez, R. \&Nicolelis M.A.L. (2006). The neural mechanisms of gustation, a distributed processing code. Nature Reviews Neuroscience, 7, 890-901.

Soukoulis, C., Biasioli, F., Aprea, E., Schuhfried, E., Cappellin, L., Märk, T.D. \& Gasperi, F. (2012). PTR-TOF-MS Analysis for influence of milk base supplementation on texture and headspace concentration of endogenous volatile compounds in yogurt. Food Bioprocess Techology, 5, 2085-2097.

Spence, C. (2011). Mouth-watering, the influence of environmental and cognitive factors on salivation and gustatory/flavor perception.Jounal Texture Studies, 42, 157-171.

Stevens, D.A., Smith, R. \& Lawless, H.T. (2006). Multidimensional scaling of ferrous sulfate and basic tastes. Physiology \& Behavior, 87, 272-279. 
Stevenson, R.J. (2009). The psychology of flavour Oxford, Oxford University Press.

Stieger, M. \& Van De Velde, F. (2013). Microstructure, texture and oral processing, new ways to reduce sugar and salt in foods. Current Opinion in Colloid Interface Science, 18, 334-348.

Stokes, J.R., Boehm, M.V. \& Baier, S.K. (2013). Oral processing, texture and mouthfeel, from rheology totribology and beyond. CurrentOpinion in Colloid\&InterfaceScience, 18, 349-359.

Syarifuddin, A., Salles, C., Septier, C. \& Thomas-Danguin, T. (2016). Reducing salt and fat while maintaining taste: an approach on a model food system.Food Quality Preference, 48, 59-69.

Szczesniak, A.S. (2002). Texture is a sensory property. Food Quality and Preference, 13, 215-225.

Szczesniak, A.S. (1990). Texture, is it an overlooked food attribute? Food Technology, 44, 86-95.

Takahashi, T., Miyamoto, T., Terao, A. \& Yokoyama, A. (2007). Cerebral activation related to the control of mastication during changes in food hardness. Neuroscience, 145, 791-794.

Tarrega, A., Yven, C., Semon, E. \& Salles, C. (2008). Aroma release and chewing activity during eating different model cheeses. International Dairy Journal, 18, 849-857.

Tarrega, A., Yven, C., Semon, E. \& Salles, C. (2011). In-mouth aroma compound release during cheese consumption, relationship with food bolus formation. International Dairy Journal, 21, $358-364$

Terta, M., Blekas, G. \& Paraskevopoulou, A. (2006). Retention of selected aroma compounds by polysaccharide solutions, a thermodynamic and kinetic approach. Food Hydrocolloids, 20, 863871.

Tournier, C. (2006). Interactions texture-flavour: mécanismesphysico- chimiques et mécanismes cognitifs? Application à un gel laitieronctueux. PhD Thesis, Université de Bourgogne, Dijon, France, p: 191.

Tournier, C., Sulmont-Rossé, C. \& Guichard, E. (2007). Flavourperception, aroma, taste and texture interactions global science books. Food, 1, 246-257.

Tournier, C., Sulmont-Rossé, C., Sémon, E., Vignon, A., Issanchou, S. \& Guichard, E. (2009). A study on texture-taste-aroma interactions, physico-chemical and cognitive mechanisms. International Dairy Journal, 19, 450-458.

Trelea, I. C., Atlan, S., Déléris, I., Saint-Eve, A., Marin, M. \&Souchon, I. (2008). Mechanistic mathematical model for in vivo aroma release during eating of semiliquid foods. Chemical Senses, 33, 181-192.

Tuorila, H. \& Hartmann C. (2020).Consumer responses to novel and unfamiliar foods. Current Opinion in Food Science, 33,1-8.

Valentin, D., Chrea, C. \& Nguyen, D.H. (2006). Taste-odour interaction in sweet taste perception. Ed.: Spillane, W.J., Optimising Sweet Taste in Foods. Cambridge, UK: Woodhead Publishing Limited, pp: 66-84.

Van Vliet, T., Van Aken, G.A., De Jongh, H.H.J. \& Hamer, R.J. (2009). Colloidal aspects of texture perception. Advances in Colloid and Interface Science, 150, 27-40. 
Ventanas, S., Mustonen, S., Puolanne, E. \& Tuorila, H. (2010a). Odour and flavour perception in flavoured model systems, influence of sodium chloride, umami compounds and serving temperature. Food Quality and Preference, 21, 453-462.

Ventanas, S., Puolanne, E. \& Tuorila, H. (2010b). Temporal changes of flavour and texture in cooked bologna type sausages as affected by fat and salt content. Meat Science, 85, 410-419.

Verhagen, J.V., and Engelen, L. (2006). The Neurocognitive Bases of Human Multimodal Food Perception: Sensory Integration. Neuroscience and Biobehavioral Reviews, 30, 613-650.

Vilgis, T.A. (2013). Texture, taste and aroma: multi-scale materials and the gastrophysics of food. Flavour journal, 2, 12.

Wang, X. \& Chen, J. (2017). Food Oral Processing, Recent Developments and Challenges. Current Opinion in Colloid \& Interface Science, 28, 22-30.

Weel, K.G.C, Boelrijk, A.E.M., Alting, A.C., Van Mil, P.J.J.M, Burger, J.J., Gruppen, H., Voragen, A.G.J. \& Smit, G. (2002). Flavor release and perception of flavored whey protein gels, perception is determined by texture rather than by release. Journal of Agricultural and Food Chemistry, 50, 5149-5155

Wilson, D.A. (2001). Receptive fields in the rat piriform cortex. ChemicalSenses, 26, 577-584.

Zafeiropoulou, T., Evageliou, V., Gardeli, C., Yanniotis, S. \& Komaitis, M. (2012). Retention of selected aroma compounds by gelatine matrices.Food Hydrocolloids, 28, 105-109. 